Biogeosciences Discuss., doi:10.5194/bg-2016-527, 2016

Manuscript under review for journal Biogeosciences

Published: 20 December 2016

(c) Author(s) 2016. CC-BY 3.0 License.

\title{
Uncertainties in global crop model frameworks: effects of cultivar distribution, crop management and soil handling on crop yield estimates
}

5 Christian Folberth ${ }^{1}$, Joshua Elliott ${ }^{2,3}$, Christoph Müller ${ }^{4}$, Juraj Balkovic ${ }^{1,5}$, James

Chryssanthacopoulos ${ }^{3}$, Roberto C. Izaurralde ${ }^{6,7}$, Curtis D. Jones ${ }^{6}$, Nikolay Khabarov ${ }^{1}$, Wenfeng Liu $^{8}$, Ashwan Reddy ${ }^{6}$, Erwin Schmid ${ }^{9}$, Rastislav Skalský ${ }^{1,10}$, Hong Yang ${ }^{8,11}$, Almut Arneth $^{12}$, Philippe Ciais ${ }^{13}$, Delphine Deryng ${ }^{3}$, Peter J. Lawrence ${ }^{14}$, Stefan Olin ${ }^{15}$, Thomas

A.M. Pugh ${ }^{12,16}$, Alex C. Ruane ${ }^{3,17}$, Xuhui Wang ${ }^{13,18}$

10

${ }^{1}$ International Institute for Applied Systems Analysis, Ecosystem Services and Management Program, 2361

Laxenburg, Austria

${ }^{2}$ University of Chicago and ANL Computation Institute, Chicago, IL 60637, USA

${ }^{3}$ Columbia University Center for Climate Systems Research and NASA Goddard Institute for Space Studies,

15 New York, NY 10025, USA

${ }^{4}$ Potsdam Institute for Climate Impact Research, 14473 Potsdam, Germany

${ }^{5}$ Comenius University in Bratislava, Department of Soil Science, 84215 Bratislava, Slovak Republic

${ }^{6}$ University of Maryland, Department of Geographical Sciences, College Park, MD 20742, USA

${ }^{7}$ Texas A\&M University, Texas AgriLife Research and Extension, Temple, TX 76502, USA

$20 \quad{ }^{8}$ Eawag, Swiss Federal Institute of Aquatic Science and Technology, CH-8600 Duebendorf, Switzerland

${ }^{9}$ University of Natural Resources and Life Sciences, Institute for Sustainable Economic Development, 1180

Vienna, Austria

${ }^{10}$ Soil Science and Conservation Research Institute, National Agricultural and Food Centre, 82713 Bratis lava, Slovak Republic

$25{ }^{11}$ Department of Environmental Sciences, University of Basel, Petersplatz 1, CH-4003 Basel, Switzerland

${ }^{12}$ Karlsruhe Institute of Technology, IMK-IFU, 82467 Garmisch-Partenkirchen, Germany

${ }^{13}$ Laboratoire des Sciences du Climat et de l'Environnement. CEA CNRS UVSQ Orme des Merisiers, F-

91191 Gif-sur-Yvette, France

${ }^{14}$ National Center for Atmospheric Research, Earth System Laboratory, Boulder, CO 80307, USA

$30 \quad{ }^{15}$ Department of Physical Geography and Ecosystem Science, Lund University, 22362 Lund, Sweden

${ }^{16}$ School of Geography, Earth \& Environmental Science and Birmingham Institute of Forest Research,

University of Birmingham, Edgbaston, Birmingham, B15 2TT, United Kingdom

${ }^{17}$ National Aeronautics and Space Administration Goddard Institute for Space Studies, New York, NY 10025, USA

${ }^{18}$ Peking University, Sino-French Institute of Earth System Sciences, 100871 Beijing, China

Correspondence to: Christian Folberth (folberth@iiasa.ac.at) 
Biogeosciences Discuss., doi:10.5194/bg-2016-527, 2016

Manuscript under review for journal Biogeosciences

Published: 20 December 2016

(c) Author(s) 2016. CC-BY 3.0 License.

Abstract. Global gridded crop models (GGCMs) combine field-scale agronomic models or sets of plant growth algorithms with gridded spatial input data to estimate spatially explicit crop yields and agricultural externalities at the global scale. Differences in GGCM outputs arise from the use of different bio-physical models, setups, and input data. While algorithms have been in the focus of recent GGCM comparisons, this study investigates differences in maize and wheat yield estimates from five GGCMs based on the public domain field-scale model Environmental Policy Integrated Climate (EPIC) that participate in the AgMIP Global Gridded Crop Model Intercomparison (GGCMI) project. Albeit using the same crop model, the GGCMs differ in model version, input data, management assumptions, parameterization, geographic distribution of cultivars, and selection of subroutines e.g. for the estimation of potential evapotranspiration or soil erosion. The analyses reveal long-term trends and inter-annual yield variability in the EPIC-based GGCMs to be highly sensitive to soil parameterization and crop management. Absolute yield levels as well depend not only on nutrient supply but also on the parameterization and distribution of crop cultivars. All GGCMs show an intermediate performance in reproducing reported absolute yield levels or inter-annual dynamics. Our findings suggest that studies focusing on the evaluation of differences in bio-physical routines may require further harmonization of input data and management assumptions in order to eliminate background noise resulting from differences in model setups. For agricultural impact assessments, employing a GGCM ensemble with its widely varying assumptions in setups appears the best solution for bracketing such uncertainties as long as comprehensive global datasets taking into account regional differences in crop management, cultivar distributions and coefficients for parameterizing agro-environmental processes are lacking. Finally, we recommend improvements in the documentation of setups and input data of GGCMs in order to allow for sound interpretability, comparability and reproducibility of published results.

60

Keywords: agricultural management; agro-ecologic systems; evapotranspiration; soil data; global agriculture

\section{Introduction}

Global gridded crop models (GGCMs) have become major tools in recent years for agricultural climate change impact assessments (e.g. Liu et al., 2013; Balkovič et al., 2014; Elliott et al., 2014; Folberth et al., 2014; Rosenzweig et al., 2014; Müller et al., 2015; Deryng et al., 2016) and water consumption studies (e.g. Liu et al., 2007; Fader et al., 2010) among others. For some models, the global gridded version is a combination of (a) a field-scale crop model, or collection of algorithms used to estimate yields and externalities of crop production for a number of pixels covering a given region and (b) a model framework (MFW) that processes input data and runs the model over large regions or the globe. The often high-complexity of these field-scale models is contrasted by the scarcity of spatially detailed input data available for global-scale applications of GGCMs. This requires assumptions on crop management and the use of agricultural inputs by modelers, which can differ substantially among research groups. Fertilizer application rates may, for example, be (a) based on statistics (Liu, 2009; Deryng et al., 2011; Folberth et al., 2012; Balkovič et al., 2014), (b) defined by contrasting intensification systems (Skalský et al., 2008), or (c) integrated into management coefficients, e.g. if a model does not contain explicit nutrient cycling routines (Fader et al., 2010). Other management related data such as the handling of crop residues, fallow durations and tillage practices have yet to be compiled at the global scale. 
Biogeosciences Discuss., doi:10.5194/bg-2016-527, 2016

Manuscript under review for journal Biogeosciences

Published: 20 December 2016

(c) Author(s) 2016. CC-BY 3.0 License.

Furthermore, the setup and parameterization of a GGCM depends on the evolving objectives used in its development. The Environmental Policy Integrated Climate (EPIC) field-scale model, which is the focus of this study, has been developed for assessing impacts of agricultural management on crop growth and externalities like erosion rates and soil nutrient cycling (Williams et al., 1989). When it comes to long-term impacts of climate change on agricultural production, however, soil erosion and nutrient depletion can affect yield estimates over time due to nutrient deficits (Kuhn et al., 2010). To limit such effects and facilitate investigations of climate impacts alone on plant growth, the model allows for annually resetting the soil profile. This in turn eliminates interactions among crop management, soil and climate beyond the annual growing season, which can be crucial for identifying effective adaptation options (Folberth et al., 2014; Folberth et al., 2016). In GGCM studies, researchers may therefore opt for one setup over another depending on the object of investigation. Besides different options of how to handle soils, the EPIC model provides six different methods for estimating water erosion, five algorithms for estimating potential evapotranspiration (PET) as well as several subroutines and suggested parameter ranges for nutrient cycling and gas diffusion within the soil (Gerik et al., 2014).

Hence, GGCMs, even of the same origin or model family, can exhibit substantial differences in simulated outputs due to uncertainties originating from (a) field-scale models or modelled processes, (b) input data, and (c) setup and parameterization. In order to systematically address uncertainties in GGCMs, the Inter-Sectoral Impact Model Intercomparison Project (ISI-MIP; http://www.isi-mip.org; Warszawski et al., 2014) and the Agricultural Model Intercomparison and Improvement (AgMIP) project (https://www.agmip.org; Rosenzweig et al., 2013) compiled outputs from various GGCMs that had been forced with identical climate projections (Hempel et al., 2013) in order to produce a joint agricultural climate change impact assessment (Rosenzweig et al., 2014). These studies revealed that large differences remain among GGCMs even if they are based on identical field-scale models. This emphasized the importance of distinguishing between biophysical plant growth models that are used as a core of GGCMs on one hand and MFWs on the other.

For phase 1 of AgMIP's Global Gridded Crop Modelling Intercomparison initiative (GGCMI; http://www.agmip.org/ag-grid/ggcmi), several GGCMs have been forced with identical annual fertilizer application rates, growing seasons and climate data to eliminate uncertainties resulting from these priority data (Elliott et al., 2015). Among the 14 GGCMs participating in the study, five were based on the EPIC model, namely EPIC-BOKU, EPIC-IIASA, EPIC-TAMU, GEPIC and PEPIC. The purpose of the present study is to identify differences among these EPIC-based MFWs caused by input data, crop management and parameterization. This allows for identifying priorities for further harmonization in the whole GGCM ensemble in order to refine analyses of differences in biophysical algorithms globally. All MFWs were run for six crop management intensities to evaluate the impact of nutrient and water supply on differences in crop yield

110 estimates. Here, we focus on maize in detail as a representative crop widely used in GGCM studies. Complementary results are provided for wheat in Supplementary Information S4 as key findings were in close agreement for both crops. In addition, various setup options were permutated for maize between two of the GGCMs, EPIC-IIASA and GEPIC, to assess the contribution of certain setup aspects to deviations in yield estimates. Outputs from an ensemble of non-EPIC-based GGCMs participating in phase 1 of the GGCMI

115 project that establishes both a general benchmark for global crop models, as well as the model-driven uncertainty in GGCM simulations (Müller et al., 2016), are used as a reference to which to compare the EPICbased ensemble. 
Biogeosciences Discuss., doi:10.5194/bg-2016-527, 2016

Manuscript under review for journal Biogeosciences

Published: 20 December 2016

(c) Author(s) 2016. CC-BY 3.0 License.

\section{Methods and Data}

\subsection{The Environmental Policy Integrated Climate field scale model}

The EPIC model was first developed in the 1980s to assess the impacts of soil management on crop yields (Williams et al., 1989). It has been updated frequently to cover e.g. effects of elevated atmospheric $\mathrm{CO}_{2}$ concentration on plant growth (Stoeckle et al., 1992), detailed soil organic matter cycling (Izaurralde et al., 2006, Izaurralde et al., 2012), and an extended number of crop types and cultivars (e.g. Kiniry et al., 1995; Gaiser et al., 2010) among others (Gassman 2004).

EPIC estimates potential biomass increase on a daily time-step based on light interception and conversion of $\mathrm{CO}_{2}$ to biomass. Plant growth and phenology are calculated based on the daily accumulation of heat units. Plant growth is constrained by water and nutrient (nitrogen $(\mathrm{N})$ and phosphorus $(\mathrm{P})$ ) deficits, adverse temperature, and aeration stress. The potential biomass gain is subsequently adjusted by the major plant growth-regulating factor on a given day to obtain the actual biomass increment. Root growth can be limited by soil strength, adverse soil temperature, and aluminum toxicity. At maturity, the model calculates crop yield based on above ground biomass and an actual harvest index $\mathrm{HIa}$, which is estimated within a range given by potential $\mathrm{HI}\left(\mathrm{HI}_{\max }\right)$ and minimum $\mathrm{HI}$ under water stress $\left(\mathrm{HI}_{\min }\right)$. Besides plant growth and yield formation, EPIC estimates a wide range of environmental externalities, for example wind and water erosion rates, turnover and partitioning of organic carbon (OC), N and P, evapotranspiration (ET), fluxes of selected gases, and soil hydrologic processes.

\subsection{EPIC model frameworks and complementary global gridded crop models included in the study}

Different versions of the EPIC model have been implemented in the five EPIC-MFWs evaluated in the study: EPIC-BOKU, EPIC-IIASA, GEPIC, and PEPIC use EPIC v.0810, while EPIC-TAMU uses the experimental version v.1102. Main differences between the two structurally very similar model versions are outlined in Supplementary S1.2, which also provides a comparison of maize yield estimates of the two model versions for four selected sites. Besides different model versions, the selection of subroutines adds to differences in the set of algorithms used for the simulations as well. E.g., EPIC allows for selecting from five estimation methods for PET, namely Baier-Robertson, Priestly-Taylor, Penman, Penman-Monteith (PM), and Hargreaves (HG). Water erosion can be estimated by one of eight methods, and there are 11 options for estimating or inputting the water content at field capacity and wilting point. In addition, individual parameters and coefficients may be adjusted by the user to adapt the model to local conditions (Gerik et al., 2014).

Table 1 provides an overview of major subroutines and parameters selected within the five EPIC-MFWs. Another seven GGCMs (CLM-CROP, LPJ-GUESS, LPJmL, ORCHIDEE-crop, pAPSIM, pDSSAT, and PEGASUS) contributing to GGCMI phase 1 were included to locate the EPIC ensemble within a wider ensemble of GGCMs based on different sets of algorithms. They were selected based on the contribution of outputs for at least two of three management setups: without nutrient limitation and default or fully harmonized input data (fullharm; see Section 2.4) for maize or wheat. If only default or fullharm was supplied, the corresponding other scenario was used as a substitute to keep the number of GGCMs across management scenarios constant.

The following sub-sections provide key descriptions of the setups and rationales of the EPIC-based MFWs. 
Biogeosciences Discuss., doi:10.5194/bg-2016-527, 2016

Manuscript under review for journal Biogeosciences

Published: 20 December 2016

(c) Author(s) 2016. CC-BY 3.0 License.

GGCMs, including the seven non-EPIC-based GGCMs that were used for comparison with the EPIC-MFW ensemble, are provided on the website of ISI-MIP (http://www.isimip.org) and in Müller et al. (2016).

\subsubsection{EPIC-BOKU}

EPIC-BOKU was initially developed to provide yield estimates at contrasting management intensities for land use change and agro-economic models (Havlík et al. 2011, Schneider et al. 2011; Nelson et al., 2014; Frank et al., 2015) at the European and global scales (Stolbovoy et al. 2007; Skalský et al., 2008; Elshout et al., 2015).

The spatial structure of its input data is based on a regular 5 arcmin grid, which is first aggregated to homogenous response units (HRUs) based on a classification of physical characteristics (elevation, slope, soil). The HRUs are subsequently intersected with administrative units (national borders at the global scale) that determine specific crop management parameters, which are derived from databases or socio-economic data. The field-scale model is run for each of the resulting simulation units (SimU). For comparison with GGCMs running at a $0.5^{\circ} \mathrm{x} 0.5^{\circ}$ resolution, the results from the SimUs were resampled based on the pixel-weighted 5 arcmin model outputs per $0.5^{\circ} \mathrm{x} 0.5^{\circ}$ grid. Presently, the GGCM runs two nutrient management intensities, high-input and low-input agriculture with accordingly high or low fertilizer application rates. For the default simulations, outputs from the high-input runs were submitted, corresponding to non-nutrient limited yield potential with default growing season assumptions. Further management data such as growing seasons have been compiled from various sources as specified in Skalský et al. (2008).

\subsubsection{EPIC-IIASA}

EPIC-IIASA has been developed in parallel to EPIC-BOKU, partly by the same researchers and shares the same spatial data structure based on HRUs and SimUs. Parameterizations and input data have been adjusted throughout research projects resulting in a substantially differing setup with the major remaining communality being the use of a static soil profile (Table 1). Growing seasons have been adopted from Sacks et al. (2010) and crop-specific spatially explicit N and P application rates from Mueller et al. (2012). Focus regions of recent studies for which model setups have been adjusted are the EU (e.g. Balkovič et al., 2013) and China (Xiong et al., 2014a; Xiong et al., 2014b) besides global applications (Balkovic et al. 2014 Xiong et al. 2016).

\subsubsection{EPIC-TAMU}

EPIC-TAMU follows the model development and implementation of EPIC, version 1102, which accounts for C and $\mathrm{N}$ stocks and flows in managed terrestrial ecosystems (Izaurralde et al. 2012). As in EPIC v. 0810, the coupled $\mathrm{C}$ and $\mathrm{N}$ model in EPIC-TAMU follows the conceptual pool structure of the Century model (Izaurralde et al., 2006). Mineralization and immobilization of $\mathrm{C}$ and $\mathrm{N}$ also follows the approach in Century but a recent option has been added to describe $\mathrm{C}$ and $\mathrm{N}$ of microbial biomass following the approach used in the Phoenix model (McGill et al., 1981). The EPIC-TAMU version also contains algorithms to model the effects of biochar additions on crop productivity, soil pH, and cation exchange capacity (Lychuk et al., 2015). Other developments include a mechanistic model to describe microbial denitrification and the corresponding feedback on decomposition (Izaurralde et al., 2012).

EPIC-TAMU has primarily been used for field-scale and regional-scale simulations (Gelfand et al., 2013; Zhang et al., 2015). It has been adapted with minimal changes for use as part of the AgMIP GGCMI project, and has 
Biogeosciences Discuss., doi:10.5194/bg-2016-527, 2016

Manuscript under review for journal Biogeosciences

Published: 20 December 2016

(c) Author(s) 2016. CC-BY 3.0 License.

otherwise not been previously used for global simulations. As a result, no default simulations (see Section 2.4) were produced. To keep the number of EPIC-MFWs in evaluations across management scenarios constant, the

\subsubsection{GEPIC}

The GEPIC MFW was originally developed for studies of global crop-water relations (Liu et al., 2007). In its present version, it uses input data for planting dates, growing season length, $\mathrm{P}$ fertilizer application rates, and cultivar distributions besides the original input data elevation, slope, country/region, $\mathrm{N}$ fertilizer application rates, and irrigation water management (Folberth et al., 2012). Default fertilizer inputs are mainly based on the FertiStat database (FAO, 2007) and have been extrapolated for maize based on the human development index (HDI) for countries lacking data.

More recently, the MFW has been setup for applications in sub-Saharan Africa based on a regional calibration (Gaiser et al., 2010) and thoroughly evaluated in various studies (e.g. Folberth et al., 2012; Folberth et al., 2014; van der Velde et al., 2014). The authors found that when using dynamic soil profiles in the setup, the model reproduces yields around the year 2000 well after a spin-up of 30 years (Folberth et al., 2012). Extending the simulation period may result in erosion of the whole soil profile at some point or complete nutrient depletion in grid cells that lack fertilizer inputs. To avoid resulting detrimental effects on crop yields and unrealistically long monocultures, the model is run for each decade of the study period separately, which aims at mimicking fallow rotation with an average cultivation period of 40 years and complete recovery of the soil profile afterwards (see Figure S1-1).

\subsubsection{PEPIC}

PEPIC is a global EPIC-MFW developed at the Swiss Federal Institute of Aquatic Science and Technology (Eawag) initially based on GEPIC, which had been developed at the same institute. Hence, the two MFWs have similar features in software design and default input data. However, one of the main purposes of PEPIC was to develop a fully free tool, which can be used without any software license. Therefore, unlike GEPIC, PEPIC was compiled by a free computer language, Python. In addition, the parameterization and setup has been adjusted in large parts (Table 1) to match focus research purposes. It was initially developed to investigate the impacts of different PET methods on crop-water relations (Liu et al., 2016a). Presently, applications of PEPIC focus on assessing trade-offs between crop yields and nutrient losses, e.g. $\mathrm{N}$, in the context of global agricultural intensification (Liu et al., 2016b). For such assessments, $\mathrm{N}$ was applied three times during the whole season following a fixed schedule (Liu et al., 2016b). Besides the parameterization, this is a single major difference compared to the other four EPIC-MFWs, which used automatic $\mathrm{N}$ fertilization based on plant nutrient requirements.

Table 1

\subsection{Common input data}

Climate forcing data based on the WFDEI GPCC dataset (Weedon et al., 2014) at a spatial resolution of $0.5^{\circ} \times 0.5^{\circ}$ were provided by the ISI-MIP and GGCMI projects. The climate data are based on temperature and 
Biogeosciences Discuss., doi:10.5194/bg-2016-527, 2016

Manuscript under review for journal Biogeosciences

Published: 20 December 2016

(c) Author(s) 2016. CC-BY 3.0 License.

solar radiation from ERA-interim (Dee et al., 2011) and precipitation from GPCC (Schneider et al., 2013). All EPIC-based MFWs used soil data from the ISRIC-WISE database (Batjes, 2006) mapped to the Digital Soil Map of the World (FAO, 1995). For EPIC-BOKU and EPIC-IIASA, the originally approx. 5000 soil profiles had been reduced to 120 based on a classification of key variables (Skalský et al., 2008) and soil hydraulic parameters not provided in the WISE databases were complemented according to Schaap and Bouten (1996) and Wösten and Van Genuchten (1988).

For the harmonized runs, nutrient application rates for $\mathrm{N}$ and $\mathrm{P}$ were based on crop-specific data from Mueller et al. (2012) to which manure application rates had been added proportionally. Separate planting dates and growing season lengths for rainfed and irrigated management were based on Sacks et al. (2010), complemented by gap filling with data from the MIRCA2000 dataset (Portmann et al., 2010) and the LPJmL model (Waha et al., 2012). Both datasets were provided by the GGCMI project (Elliott et al., 2015). Default runs (see Sect. 2.4; Table 2) were carried out using individual fertilizer and growing season databases within each MFW.

\subsection{Crop management scenarios}

Six crop management scenarios (Table 2) were simulated to quantify differences among MFWs based on three steps of growing season and nutrient supply harmonization. Each of these three scenarios was simulated with two water management scenarios, rainfed only or sufficiently irrigated.

The default scenario represents each research group's assumptions on fertilizer application rates and growing seasons (see Sect. 2.2). It serves for evaluating differences among MFWs if only climate data are harmonized. The fully harmonized (fullharm) setup allows for identifying remaining differences if annual nutrient application rates and growing seasons are harmonized using the input data described in Sect. 2.3. The fully harmonized setup with sufficient nutrient application (harm-suffN, referred to as harmnon in the simulation protocol published by Elliott et al. 2015) virtually eliminates plant nutrient deficits and consequently impacts of soil nutrient dynamics. This is expected to minimize differences among MFWs resulting from the setup of fertilizer application and soil nutrient cycling.

Irrigation water is applied in all MFWs up to a sufficient amount automatically based on plant water requirement in the irrigated management scenarios. The application takes place based on varying thresholds (1$20 \%$ plant water stress, see Supplementary S1) in the MFWs.

Table 2

\subsection{Geographic distributions of maize cultivars}

260 Crop cultivars are here considered to be defined by $\mathrm{HI}_{\min }, \mathrm{HI}_{\max }$, and optimal temperature ranges only, whereas the heat unit requirement is prescribed by growing season input data. Between one and four different maize cultivars were planted within each MFW (Figure 1; Table S1-1). EPIC-IIASA uses four cultivars in its default setup (Figure 1a) that are attributed to major world regions based on climatic and economic characteristics. The same geographic distribution of cultivars was used for EPIC-IIASA in the harmonized setup scenarios except that the early and late maturing high-yielding cultivars 1 and 3 were merged as growing season length was defined according to common input data sets (see Sect. 2.4). EPIC-TAMU (Figure 1b) plants one high-yielding and one low-yielding variety. The latter was attributed to countries, in which maize yields stagnated or 
Biogeosciences Discuss., doi:10.5194/bg-2016-527, 2016

Manuscript under review for journal Biogeosciences

Published: 20 December 2016

(c) Author(s) 2016. CC-BY 3.0 License.

decreased within the past decades according to Ray et al. (2012), the first to all other. The same two maize cultivars were distributed in the GEPIC and PEPIC MFWs (Figure 1c) based on the HDI. The high-yielding variety is planted in all countries with $\mathrm{HDI} \geq 80$, which corresponds to high development. EPIC-BOKU used the high-yielding variety in all grid cells (Figure 1d).

Figure 1

\subsection{Permutation of setup options for GEPIC and EPIC-IIASA}

To better identify the importance of single data and parameterization domains within the MFWs, selected aspects of model setups were exchanged between EPIC-IIASA and GEPIC. These were grouped into the domains of cultivar distribution (Cult), soil data (SoilD), soil handling (SoilP), crop management (Manage) and miscellaneous coefficients (Coeff) (Table 3). The GEPIC model was run with all 32 resulting setup combinations using the land mask of EPIC-IIASA to ensure consistency. The evaluation focused on rainfed yield estimates as these cover the whole range of uncertainty impacts. Yield estimates based on sufficient irrigation were used to identify differences based on soil hydrology and other factors affecting water limitations to plant growth

Table 3

\subsection{Reported yield data and evaluation}

Unless otherwise specified, all results were evaluated for the period 1980-2009, which corresponds to the span of the climate data across growing seasons in both hemispheres. Annual national average crop yields from the FAOSTAT database (FAO, 2014) were used for assessing model performance. Reported yields were de-trended using a 5-year moving mean average in order to remove trends in yields due to changes in technology and management. Model performance, which served here solely for comparing differences in model skills in relation to differences in setups, was evaluated using time series correlation (tscorr) between national average simulated and reported yields using Pearson's product moment correlation coefficient $r$. A tscorr of $r>0.5$ (corresponding to more than $50 \%$ of variance explained by the model) was selected as threshold for good model performance. The coefficient of variation $(\mathrm{CV})$ was used as a metric of deviation among yield estimates from different MFWs.

National average yields $\left(Y D_{a v}\right)$ were calculated from simulated rainfed and irrigated yields in each grid cell and the respective rainfed and irrigated harvested areas (Portmann et al., 2010) according to:

$Y D_{a v, c}=\frac{\sum_{g=1}^{m}\left[Y D_{i, g} \times H A_{i, g}+Y D_{r, g} \times H A_{r, g}\right]}{\sum_{g=1}^{m}\left[H A_{i, g}+H A_{r, g}\right]}$

300

where $Y D_{a v, c}$ is the national average yield in country $c, Y D_{i, g}$ is yield under irrigated conditions in grid cell $g$, $Y D_{r, g}$ is yield under rainfed conditions in grid cell $g, H A_{i, g}$ is irrigated area in grid cell $g$, and $H A_{r, g}$ is rain fed area in each grid cell $g$, and $m$ is the number of grid cells in country $c$. We acknowledge the uncertainty 
Biogeosciences Discuss., doi:10.5194/bg-2016-527, 2016

Manuscript under review for journal Biogeosciences

Published: 20 December 2016

(c) Author(s) 2016. CC-BY 3.0 License.

introduced from spatial aggregation (Porwollik et al., 2016) but as the focus is on a comparison of MFWs, we

All evaluations were carried out with the statistics software R (R Development Core Team, 2008) using the packages ggplot2 (Wickham, 2009) and the heatmap.2 function of gplots (Warnes et al., 2016) in a modified version by Müller et al. (2016)

\section{Results}

\subsection{Global average maize yields}

If the GGCMs are run in their default setups, global average simulated maize yields differ by up to $124 \%$ annually (mean 95\%) using the lowest estimate as a reference (Figure 2a; Table S2-1). This is mainly due to very high yield estimates from EPIC-BOKU of around $8 \mathrm{t} \mathrm{ha}^{-1}$, while the other EPIC-MFWs have yield estimates of around 4-6 tha $\mathrm{ha}^{-1}$. The ranges decrease to $55 \%$ if harmonized planting dates and fertilizer application rates are used (Figure $2 \mathrm{~b}$ ) and further to $26 \%$ with sufficient nutrient supply (Figure 2c). In addition, the order of EPIC-MFWs mean biases changes. While EPIC-BOKU has the highest average default yield estimates, the highest yields simulated given sufficient nutrient supply and harmonized growing seasons are from EPIC-IIASA and EPIC-TAMU.

EPIC-BOKU and PEPIC exhibit declining yield trends over the simulation period, whereas the other EPICMFWs do not exhibit any trend. For PEPIC this is most pronounced in the default setup, for EPIC-BOKU in the harm-suffN scenario, in which it initially provides the highest yield and at the end of the simulation period one of the lowest. The inter-annual yield variability shows very similar patterns among all MFWs. The whole EPICMFW ensemble indicates a peak in global average yield in 2004, which is also apparent in the reported data and the non-EPIC-based GGCMs (Figure S2-1).

The continuous decrease in the spread among EPIC-MFWs with increasing level of harmonization and elimination of nutrient limitations is contrasted by an increasing spread for the non-EPIC-based GGCMs (Figure S2-1), comprising the models CLM-CROP, LPJ-GUESS, LPJmL, pAPSIM, pDSSAT, and PEGASUS as ORCHIDEE-crop provided data for the harm-suffN scenario for wheat only (see Supplementary Information S4). This is mainly driven by very high yield estimates by two of the non-EPIC-based GGCMs and very low estimates by one, whereas three of the non-EPIC-based GGCMs estimate yield potentials at a similar level as the EPIC ensemble. Besides this increase in spread among MFWs, the range of yields is in the fullharm scenario among the non-EPIC-based GGCMs about three times as large as among the EPIC-MFWs.

Figure 2

\subsection{Spatial patterns of differences in maize yields among model frameworks}

No clear relationship between maize cultivar distribution and differences in maize yields could be identified (Figure S2-6). Spatially, the deviation of maize yield estimates among the MFWs is largest with the default setups in tropical and arid regions with CVs of up to $224 \%$ and $\mathrm{CV} \geq 50 \%$ in $>44 \%$ of all grid cells (Figure 3; Figure S2-2; Table S2-2). The most distinct differences were found in sub-Saharan Africa, particularly the countries of Angola and Mozambique. Large differences with CVs around 100\% occur also in South America, 
Biogeosciences Discuss., doi:10.5194/bg-2016-527, 2016

Manuscript under review for journal Biogeosciences

Published: 20 December 2016

(c) Author(s) 2016. CC-BY 3.0 License.

India, and Southeast Asia. The lowest differences with CV usually $<100 \%$ and often $<50 \%$ are found in mid and high latitudes of both hemispheres, where (a) yields are at moderate or high levels, (b) most models plant the same high-yielding cultivar and (c) the annual temperature curve usually defines a narrow growing season window. Rainfed cultivation results in larger differences among models in (semi-)arid regions of Central and West Asia, the Western USA and North-eastern Brazil. If irrigation water is applied by the MFWs, differences increase in most parts of sub-Saharan Africa and Central India, but decrease in most of North and South America, Central Asia, and Europe.

Harmonizing fertilizer and growing season data substantially reduces the CV among models to $\leq 64 \%$ under rainfed and $\leq 54 \%$ under irrigated conditions in $75 \%$ of all grid cells (Table S2-2). Spatial patterns remain largely similar to those found for the default managements. However, the CV increases in a few regions after harmonization. E.g., in the low fertilizer input region Western Russia EPIC-IIASA, which plants here a cultivar adapted to colder climates, provides high yields in comparison to the other EPIC-MFWs, which raises CV from around $30-40 \%$ in the default setups to often $50-60 \%$ in the fullharm ensemble. Also, in the semi-arid region of North-eastern Brazil, EPIC-IIASA provides very high yields, while EPIC-BOKU and EPIC-TAMU do so in Southern China. Both regions have reported growing season lengths $>200$ days, which may amplify differences in nutrient application, soil hydrology, and planted cultivars.

The application of sufficient nutrients further reduces differences among MFWs. Under irrigated conditions, the $\mathrm{CV}$ is now in $50 \%$ of the grid cells $\leq 25 \%$ and under rainfed conditions $\leq 29 \%$. Differences among model frameworks decrease especially in regions with low or moderate reported fertilizer application rates such as India, sub-Saharan Africa, and South America. Large CVs remain in the same regions as in the fullharm setup, foremost in Southern China.

Figure 3

\subsection{Impact of fertilizer supply on maize yield deviations}

The patterns observed in Figure 3 indicate that yield estimates differ especially in low-input regions. Accordingly, differences in yield estimates decrease among models with increasing $\mathrm{N}$ application rates (Figure 4). This relationship is more evident under irrigated than under rainfed conditions. The CV is on average at about $60-85 \%$ in all climate regions at very low $\mathrm{N}$ application levels and highest in arid regions under irrigated conditions. It decreases on average to about $21-23 \%$ in arid and temperate regions and $16-17 \%$ in tropical and cold regions at applications rates above $150 \mathrm{~kg} \mathrm{~N} \mathrm{ha}^{-1} \mathrm{yr}^{-1}$. Rainfed cultivation virtually eliminates nutrient application rates as a driver for differences among models in (semi-) arid climates and dampens the effect of nutrients substantially in temperate climates. Rainfed cultivation in cold and tropical regions in contrast shows similar patterns to that with sufficient irrigation, but with higher $\mathrm{CV}$ values especially at higher nutrient application rates. 
Biogeosciences Discuss., doi:10.5194/bg-2016-527, 2016

Manuscript under review for journal Biogeosciences

Published: 20 December 2016

(c) Author(s) 2016. CC-BY 3.0 License.

\subsection{Impact of single setup options on maize yield estimates}

The permutation of model setup options among the MFWs EPIC-IIASA and GEPIC (Table 3) for the fullharm scenario under rainfed conditions shows general principles and interdependences of several of these parameterization domains (Figure 5; see Figure S2-4 for relative differences among scenarios). For a description of the coefficient groups compared here see section 2.6 above. A leading "g" in the coefficient name in Figure 5 and the text indicates that the parameters are taken from the GEPIC MFW, whereas a leading "e" indicates that the parameters are from the EPIC-IIASA MFW. A summary of the key findings is provided in Table S2-3. If a static soil profile is assumed (eCoeff, columns one and three in Figure 5), there is hardly any impact of the soil handling (SoilP). In addition, the residue management (line color) hardly affects yield levels, in contrast to a dynamic soil profile (gCoeff) where the management of GEPIC (gManage) allows for higher yields at any point. If sufficient irrigation water is supplied (Figure S2-3), however, a difference in yield estimates is apparent also for eCoeff runs. This can be linked to the higher sensitivity of the model for nutrient limitations if sufficient water is supplied and faster turnover of plant residue at adequate soil humidity. Besides these nutrient-related effects, selecting the eCoeff setup domain results in a positive yield trend, which must be attributed to precipitation in the climate input data as there are no transient effects of soil management and the trend cannot be observed in the irrigated management. Selecting gCoeff, in contrast, results in a negative yield trend, larger amplitude in inter-annual yield variability, and an apparent effect of plant residue management. This trend is more pronounced if the model runs are carried out fully transiently (eSoilP) rather than on a decadal basis (gSoilP).

Figure 5

The choice of soil data (SoilD; rows one and two vs. three and four) has an impact on inter-annual yield dynamics, especially if the parameterization and soil handling of EPIC-IIASA (column one) is used. As the effect of soil data is less apparent in permutations with a stronger influence of soil nutrient dynamics (e.g. gCoeff; columns two and three), the difference can be traced to differences in soil hydrology. This is supported by the fact that differences in yield dynamics are less pronounced if sufficient irrigation water is supplied (Figure S2-3). However, the identification of an exact driver will have to be subject to detailed evaluations at the site scale altering one parameter at a time.

The choice of cultivar distribution foremost affects the magnitude of yields with about $20 \%$ higher yields for the distribution used in EPIC-IIASA (rows one and three vs. two and four in Figure 5). This corresponds closely to the differences in $\mathrm{HI}_{\max }$ between the cultivars (Table S1-1) and their distribution across the global maize harvested area (Figure 1a, c). In addition, there is an effect on inter-annual yield dynamics if sufficient irrigation

410 water is supplied and the parameterization and soil handling of GEPIC is used (Figures S2-3 and S2-5, column four). In this case, the maize distribution of EPIC-IIASA shows larger inter-annual variability with higher peaks for example in the early 1990s and 2000s.

\subsection{Differences in the performance of model frameworks and setups}

The time series correlation (tscorr) between annual national average yields and detrended reported yields shows a mixed picture of MFW performance for maize (Figure 6a). The ranking order of the EPIC-MFWs by number 
Biogeosciences Discuss., doi:10.5194/bg-2016-527, 2016

Manuscript under review for journal Biogeosciences

Published: 20 December 2016

(c) Author(s) 2016. CC-BY 3.0 License.

of countries (in parentheses) in which each respective MFW has the highest Pearson correlation coefficient $r$ regardless of its magnitude (Figure 6a) is EPIC-BOKU (37), EPIC-TAMU (36), EPIC-IIASA (35), GEPIC (30), and PEPIC (21). Considering only countries with $r>0.5$, the proportion remains similar with EPIC-TAMU (17), EPIC-IIASA (10), EPIC-BOKU (7), GEPIC (5) and PEPIC (4). However, in various countries more than one MFW has $r>0.5$ (Figure 6b). When considering all incidences in which an MFW has $r>0.5$ (see also Figure S31), the gap among MFWs narrows down with EPIC-TAMU (30), EPIC-IIASA (25), EPIC-BOKU (23), GEPIC (22), and PEPIC (22). Spatially, none of the MFWs exhibits a distinctively high performance in any part of the world defined by management intensity or climate conditions. In general, the performance is poorest in tropical regions around the equator. Out of the ten countries with the largest maize production volumes (Figure S3-2), seven have a tscorr with $r>0.5$ for at least one MFW, and all MFWs exhibit a high performance in the USA and France.

Figure 6

Testing the permutations of setup options for performance in reproducing reported maize yields does not reveal a strong tendency towards one of the two MFWs nor a spatial pattern of optimal setups (Figure 6c; Figure S3-3). Various countries show the best performance if mostly the setup options from EPIC-IIASA are used in combination with the coefficients and/or management of GEPIC (e.g. Brazil, Canada, Mexico, or Zambia). In turn, an optimal setup mostly based on GEPIC combined with management operations or soil data of EPICIIASA can be found e.g. in Greece, Italy or Japan. In most countries, the highest performance is achieved with a rather even mix of setup options from both MFWs. Thereby, the setup components soil data, soil handling, and coefficients of EPIC-IIASA have a slightly higher frequency of 53-55\% and the management a slightly lower with $49 \%$ in the optimally performing setups (Figure S3-3). The cultivar distribution of EPIC-IIASA in contrast shows the best performance in $72 \%$ of all countries. However, as the cultivar distributions of both MFWs are identical in various countries, also the GEPIC cultivar distribution shows the best performance in $60 \%$ of all countries. These figures are similar if only countries with tscorr $r>0.5$ are considered, but the frequency of better performing EPIC-IIASA setup domains increases for coefficients to $63 \%$ and the performance of cultivar distributions changes to $75 \%$ for EPIC-IIASA and $54 \%$ for GEPIC.

Still, often various setup permutations show a comparably good performance in most countries (Figure 6d; Figure S3-3). Out of the countries with tscorr $r>0.5$, only Benin, Lithuania, and Peru have a high agreement for only one or two setups. In particular European countries, south-east African countries, the USA and Thailand exhibit a good agreement with often more than 20 and up to all 32 setup variations. For single countries, certain setup domains or their combinations can be identified as affecting model performance (Figure S3-3; Figure S34). For example, in Argentina, the coefficients of GEPIC cause a lower performance compared to each equivalent simulation with EPIC-IIASA coefficients. This is the opposite, although to a lesser extent, in China. In India, the coefficients of GEPIC combined with the management of EPIC-IIASA lead to lower model performance especially if combined with the cultivar distribution of EPIC-IIASA. 
Biogeosciences Discuss., doi:10.5194/bg-2016-527, 2016

Manuscript under review for journal Biogeosciences

Published: 20 December 2016

(c) Author(s) 2016. CC-BY 3.0 License.

\section{Discussion}

\subsection{Crop distributions and parameterizations in the model frameworks}

The analyses performed here do not allow for identifying optimal maize cultivar distributions based on the EPIC-MFWs yield estimates and observations. This is due to the wide range of differences among EPIC-MFW setups and will hence have to be subject of a focus study. From a general point of view, each of the four approaches for spatially distributing maize cultivars (in terms of optimum temperature ranges and $\mathrm{HI}$ as defined in Table S1-1) globally used by the EPIC-MFWs follows logical rules but with differing rationales. The zoning approach based on agro-climatic and economic regions used in EPIC-IIASA (Figure 1a) accounts for climatic adaptation of cultivars as well as access to improved seeds. Using reported long-term yield dynamics to distribute maize cultivars as in EPIC-TAMU (Figure 1b) takes processes in agricultural development into account. The HDI used in GEPIC and PEPIC (Figure 1c) reflects socio-economic means for investing in improved inputs and access to knowledge. Finally, planting the same cultivar globally as done in EPIC-BOKU

(Figure 1d) ensures high spatial comparability of plant growth processes in the model. However, none of the approaches can be considered to fully reflect the actual distribution of maize cultivars, including the challenging problem of sub-grid heterogeneity. Already the fact that there are strongly differing domestic agricultural systems in large transition countries like Brazil, China and India implies the requirement for a more nuanced approach of distributing cultivars. As neither the national, nor the subnational, socio-economic situation can fully serve as a proxy for agricultural management intensities, a global characterization of agricultural production systems will be required to develop a valid dataset for current maize cultivar distributions. Such a baseline distribution, along with characterization of the drivers will also be a crucial first step for developing realistic projections of future cultivar distribution under environmental change.

\subsection{Drivers for differences in maize yield estimates}

\subsubsection{General setup components}

The largest differences for global average maize yield estimates among EPIC-MFWs in their default setups (Figure 2) result from the planting of a high-yielding cultivar and uniformly high fertilizer supply in EPICBOKU, contrasted by present fertilizer inputs and expansive planting of a low-yielding cultivar in GEPIC and PEPIC. The inclusion of a dynamic soil profile and soil erosion in the latter two further adds to this. EPICIIASA and EPIC-TAMU have lower extents for planting the low-yielding cultivar and use a static soil profile and/or full water erosion control in their setups. In contrast to the other EPIC-MFWs, PEPIC exhibits a negative yield trend over time. This can be attributed to the use of fixed fertilizer application schedule in PEPIC (see section 2.2.5) in contrast to automatic application based on plant requirements in the other EPIC-MFWs, which typically increase nutrient losses, and the inclusion of soil erosion combined with fully transient model runs. Both of which have been shown to affect yield trends in the model before (Liu et al., 2016b). The fact that the mean bias among EPIC-MFWs becomes very small with sufficient nutrient supply highlights that nutrient supply is the main driver for differences in mean model bias. However, the remaining differences in inter-annual yield variability indicate that yield estimates in individual years are not only affected by climate but also strongly by additional factors such as parameterization of soil hydrology and evapotranspiration, cultivars, and timing of irrigation water supply. 
Biogeosciences Discuss., doi:10.5194/bg-2016-527, 2016

Manuscript under review for journal Biogeosciences

Published: 20 December 2016

(c) Author(s) 2016. CC-BY 3.0 License.

The facts that the non-EPIC-based GGCM ensemble shows a relative increase in the mean range of yield estimates with increasing level of harmonization and that the spread among non-EPIC-based GGCMs in the fullharm scenario is about three times the spread among the EPIC-based MFWs (Figure S2-1) highlight that the uncertainty introduced by differences in parameterization and input data in the same model is still far lower than uncertainties related to conceptual differences among models. These have been characterized in Müller et al. (2016) and on https://www.isimip.org/impactmodels. General differences such as the inclusion of certain climate variables and employment of contrasting representations of photosynthesis and biomass partitioning may have less of an effect on this phenomenon. More importantly, the models take soil characteristics (and hence their limiting effects) into account at varying levels of detail, have cultivars based on plant functional types or specific crop cultivars, and have explicit representations of nutrient supply or include these through aggregated management coefficients. In addition, several of the GGCMs have been calibrated to reproduce present yield levels in their default setups, either by altering such management coefficients, or by fitting the crop phenology. In these cases, changing growing season and fertilizer input data typically results in new combinations of these fitted variables and agronomic conditions, which can cause the observed yield estimates far above or below the reported levels despite the good fit in the default setups. The EPIC model in contrast was specifically developed to investigate impacts of crop management on yields and due to the same set of algorithms employed in the EPIC-MFWs an increasingly good fit could be expected with increasing level of harmonization.

\subsubsection{Spatial differences among model frameworks and effects on yield estimates}

510 Spatially, low yields and tropical climate are characteristic of regions in which the EPIC-MFWs show large differences in maize yield estimates in their default setups (Figure 3). The large CV is in part a result of the low yield estimates in EPIC-IIASA, EPIC-TAMU, GEPIC and PEPIC, resulting in a low mean yield, but is mainly due to the estimation of yield potential by EPIC-BOKU (Figure 2a). Besides fertilizer inputs, assumptions about growing seasons differ more strongly in tropic and warm arid regions, where cropping is often possible throughout the whole year, in contrast to temperate and cold climates which usually provide only a narrow growing-season window. The fact that irrigation increases differences among EPIC-MFWs in parts of subSaharan Africa and India is mostly due to further increases of non-nutrient-limited yield potential estimates in EPIC-BOKU. An additional minor effect is the elimination of plant water stress, which amplifies differences among the other EPIC-MFWs due to a higher sensitivity of EPIC to differences in nutrient supply (see Sect. 2.1). This is most pronounced in low-input regions, where nutrient supply depends on the parameterization of soil nutrient cycling and crop residue management.

The harmonization of annual nutrient application rates and growing season dates decreases the differences among EPIC-MFWs substantially. The main driver is the adoption of reported fertilizer application rates in EPIC-BOKU. The effect is hence largest in present low-input regions such as sub-Saharan Africa, South America and parts of Asia. The larger differences under rainfed conditions - mostly in (semi-)arid regions - may be attributed to differences in soil hydrology based on differing soil data, tillage and residue management, and the parameterization of soil and runoff processes, all of which affect plant water availability (see Folberth et al., 2016). Smaller differences remain in Europe, the USA, Oceania, Japan and southern South America where the predominant use of high-yielding maize cultivars is reflected in all MFWs. 
Biogeosciences Discuss., doi:10.5194/bg-2016-527, 2016

Manuscript under review for journal Biogeosciences

Published: 20 December 2016

(c) Author(s) 2016. CC-BY 3.0 License.

The application of sufficient nutrients mostly leaves $\mathrm{CV}<40 \%$ for maize yields among models. The remaining difference can to a large extent be explained by the use of different maize cultivars, which differ by about $50 \%$ in genetic yield potential if the lower value is used as a base. As nutrient supply from the soil is virtually eliminated in this management scenario, factors affecting plant available water, such as estimation routines for PET, runoff, and soil hydrology (Table 1) also contribute to remaining uncertainties. If sufficient irrigation water is supplied, major differences in setups remain in fertilizer (threshold for automatic application or timing of rigid application) and irrigation water (threshold for automatic application and maximum volumes) application.

Although the CV among EPIC-MFWs decreases substantially with harmonization of growing seasons and fertilizer rates, and further with application of sufficient nutrients, the global deviation among crop yield estimates is still too large to allow for a detailed quantification or ranking of drivers in these deviations. For example, low yields may occur as well if a high-yielding cultivar is planted and soil nutrients are depleted (e.g. from long-term cultivation or soil erosion) or if a low-yielding cultivar is planted and moderate amounts of fertilizer are applied (see Folberth et al., 2012). Substantial differences remain among the model setups when it comes to processed soil data, soil nutrient cycling and the handling of crop residues after harvest. All of these are major determinants for nutrient availability if exogenous nutrient application is low or completely lacking. The remaining differences among yield estimates highlight that a further harmonization may need to prioritize the handling of fertilizer application (i.e. thresholds for automatic application or timing for fixed rates) in the MFWs besides the parameterization of soil nutrient dynamics, soil data itself and the handling of crop residues. Recently, the substantial impact of soil type selection in the EPIC framework GEPIC has been evaluated in detail by Folberth et al. (2016) showing that soil data can drive absolute yield levels as well as inter-annual yield dynamics and the crop's sensitivity to adverse climate conditions. While a harmonization of soil data is difficult across a range of GGCMs with highly differing conceptual treatment of soil processes and required variables, phase 2 of the GGCMI project prescribes a rigid fertilizer application schedule to eliminate this source of uncertainty.

The largest differences remain in the tropics, thus highlighting the need for more extensive model evaluations and data collection in these regions. Continuous high temperatures and humidity levels in the tropics allow for a rapid turnover of organic material like plant residue. At the same time, mineral nutrient application rates are often low in these regions, i.e. most of Sub-Saharan Africa and parts of South America. The parameterization of these turnover processes can here be a key factor for minimizing differences among EPIC-MFWs, which is also indicated by the large differences among EPIC-MFWs in low-input grid cells (Figure 4). Furthermore, we find the distribution of maize cultivars among EPIC-MFWs differs the most in these regions. This input can be considered a priority for harmonization when it comes to reproducing absolute yield levels but - due to differences in water stress sensitivity among different cultivars - also in the estimation of inter-annual yield variability.

565 Concerning the cold and temperate zones, a recent study based on PEPIC has shown that the choice of the PET estimation method causes the largest differences in these regions (Liu et al., 2016a). It will hence need to be tested, how an ensemble of GGCMs reacts to different choices of PET estimation methods. 
Biogeosciences Discuss., doi:10.5194/bg-2016-527, 2016

Manuscript under review for journal Biogeosciences

Published: 20 December 2016

(c) Author(s) 2016. CC-BY 3.0 License.

\subsection{Impact of single setup domains on maize yield estimates}

The comparison of EPIC-IIASA and GEPIC shows that both EPIC-MFWs are capable of producing fairly stable yield levels over time within their respective setups, which is essential for estimating climate change impacts on crop yields without bias from trends in soil quality. However, they differ substantially in magnitudes of yields as well as in inter-annual yield variability. The latter can be traced to (a) the use of static vs dynamic soil profiles, (b) cultivars with different water stress sensitivity, and most importantly (c) the parameterization and choices of subroutines as specified in Table 1 .

Both EPIC-MFWs use the Hargreaves method (Hargreaves and Samani, 1985) to estimate PET, but with different parameterizations. GEPIC uses the original exponential coefficient and a linear coefficient that had been adjusted by the EPIC developers for prior studies. Vice versa, EPIC-IIASA uses the original value for the linear coefficient and an adjusted exponential coefficient. Neither of the two parameterizations can be considered more favorable than the other for global-scale applications, as PET estimation methods in general require a local calibration (e.g. Gavilán et al., 2006). This is presently not feasible at the global scale due to lack of validation data. The selected parameter values cause higher PET in GEPIC at low to moderate daily temperature ranges, especially at high average temperatures and higher PET in EPIC-IIASA at high diurnal temperature ranges. An effect is that GEPIC has a higher likeliness of water stress in most climate regions, except for deserts and mountain ranges, where large differences in day and night time temperatures are common. In addition, the soil evaporation coefficient had been lowered in EPIC-IIASA from its default value, which decreases the fraction of ET evaporating from soils. All these hydrologic factors contribute to differences among the EPIC-MFWs in inter-annual yield variability when comparing columns one and two or three and four of Figure 5 and Figure S2-4.

As the parameterizations of the two EPIC-MFWs were exchanged collectively, however, other parameters discussed above for the whole ensemble such as plant stress thresholds for fertilizer application and coefficients for microbial turnover of soil organic matter (SOM) also play a role here. The upper limit for denitrification was set very low in GEPIC due to prior applications for sub-Saharan Africa based on a calibration of the EPIC model for the region (Gaiser et al., 2010), whereas denitrification was allowed to be high in EPIC-IIASA. The microbial decay rate, a coefficient for turnover rates of SOM, in contrast, was strongly limited in EPIC-IIASA and set to a default value corresponding to no limitations due to microbial activity in GEPIC. The latter causes more rapid mineralization of nutrients from SOM. This drives differences between the two MFWs regarding residue management and nutrient cycling. Also the option of using a dynamic or a static soil profile contributes substantially to crop yield estimates. Depending on the climate and management, the static soil profile can in each year potentially provide the same amount of nutrients from SOM mineralization whereas the dynamic soil profile will experience soil nutrient depletion in low-input regions before being reset after a decade (see Supplementary 1). This may cause the overall more negative yield trends in the gCoeff scenarios and contributes to differences in inter-annual yield variability due to diverging handling of soil structure and SOM across growing seasons.

The soil data used in the two models are based on the same dataset but have been aggregated to different standardized soil profiles for EPIC-IIASA as described in Sect. 2.3. Still, organic carbon (OC) contents are identical in $>75 \%$ and within a range of $\pm 20 \%$ in nearly $90 \%$ of all grid cells globally, which renders nutrient availability from initial SOM a minor determinant for differences in yield estimates (not shown). A major 
Biogeosciences Discuss., doi:10.5194/bg-2016-527, 2016

Manuscript under review for journal Biogeosciences

Published: 20 December 2016

(c) Author(s) 2016. CC-BY 3.0 License.

difference is that water content at field capacity and wilting point, as well as hydraulic conductivity, are being estimated by different pedotransfer functions in the two MFWs (Table 1). This causes on average about 10\% higher rainfed yield estimates in EPIC-IIASA (Figure 5, column one), an effect that is largely cancelled if sufficient irrigation water is supplied (Figure S2-3 and Figure S2-5, column one), and emphasizes the importance of high resolution and quality soil data, as well as also raising questions about how to handle subgrid heterogeneity in such parameters (e.g. Folberth et al., 2016).

The cultivar distribution predominantly scales absolute yield levels. Based on $\mathrm{HI}_{\max }$ of the cultivars and their coverage within the two MFWs, the genetic yield potential is $19 \%$ lower in the GEPIC dataset than in EPICIIASA. This corresponds closely to the difference observed among the corresponding yield estimates (Figure 5, rows one and three vs. two and four). The $\mathrm{HI}_{\min }$ under water stress for cultivar 1 affects yield estimates only under severe water stress. This influences the inter-annual yield variability by causing disproportionately lower yields in extremely dry years. Apart from the HI also the temperature response of cultivar 3 used in the EPICIIASA setup has an impact on crop phenology and hence inter-annual yield variability. The performance when using the EPIC-IIASA cultivar distribution if better in various Eurasian countries in which this cultivar is planted, such as Albania, Austria, Czech Republic, Germany, Luxembourg, Moldova, and Slovakia (Figure S33). However, also the default cultivar 1 used in GEPIC in the same region shows in some instances a better performance, e.g. in Belgium, Bulgaria, and Greece.

\subsection{Model framework performances in estimating reported crop yields}

As the variability in observed national yield time series is often also driven by non-weather related variability of unknown importance, GGCMs cannot be expected to explain yield variability in all countries. Müller et al. (2016) established a first benchmark for GGCM performance where the EPIC-MFWs show similar performance to the other GGCMs in that study. Here, a good agreement between estimated and reported yields was found for various major producing countries, where fertilizer inputs are usually moderate to high and stable harvest area distributions within countries (as assumed in the constant global harvested areas dataset used for evaluations) can be expected In low-input regions in contrast, there is commonly little agreement with reported yields. This has various reasons such as (a) management may be very particular, e.g. slash and burn agriculture or crop rotations that are commonly not reflected in the GGCMs, (b) yields depend strongly on agro-environmental processes such as nutrient cycling, (c) plant protection measures are often low, rendering the impact of pests and diseases larger than in high-input regions, (d) yields reported in global databases have often been estimated, and (e) cultivars may be highly adapted to local environmental conditions and consumer preferences. In addition, the fact that EPIC takes only the major stress (out of nutrient deficit, water deficit, adverse temperature, and limited root aeration) on each day of the growing season into account to limit biomass production implies interactions between nutrient input levels and the model's sensitivity to weather-induced stresses. This approach thus lowers the crop's sensitivity to water and temperature stress if nutrient deficits are prevailing.

General conclusions as to which setup factors improve the performance in certain countries are challenging to draw. The setup options represent highly aggregated domains with more than 20 parameters included in the coefficient setup domain alone (Table 1). One setup factor that can clearly be identified to allow for higher performance in Argentina and India are the coefficients of EPIC-IIASA, which result in all 16 combinations in a tscorr with $r>0.5$ (Figure S3-4). However, in both countries there are also two setups based on the 
Biogeosciences Discuss., doi:10.5194/bg-2016-527, 2016

Manuscript under review for journal Biogeosciences

Published: 20 December 2016

(c) Author(s) 2016. CC-BY 3.0 License.

parameterization of GEPIC in combination with GEPIC's soil handling that allow for $r>0.5$. Vice versa, the parameterization of EPIC-IIASA causes a worse performance in Brazil if combined with the soil data of EPICIIASA, but a high tscorr if combined with the cultivar and soil data of GEPIC. The most dramatic contrast in setups and their performance is found in Indonesia and Ukraine, where those resulting in higher performance in the first cause lower performance in the latter, albeit none of the scenarios yields $r>0.5$. Identifying country- or region-specific optimal setups will hence require an even wider range of setup permutations, ideally based on more detailed datasets or the inclusion of findings from local and field-scale model studies that allow for reducing the dimensions of such an exercise. Also, the different setups can represent part of the variability in management systems that are present in actual production systems but greatly underrepresented in modelled production systems.

Besides setups and algorithms of the models, also input data (e.g. Ruane et al., in preparation), validation data (Müller et al., 2016), and landuse masks (Porwollik et al., 2016) affect model performance, complicating its evaluation (see Müller et al. 2016). Thus, the focus of this study was not on model performance per se, but rather on identifying differences among EPIC-MFWs that substantially affect model performance.

\section{Conclusions}

The results presented herein highlight the limited comparability of outputs from various GGCMs based on the same, or very similar, sets of biophysical algorithms, but with differences in parameterizations and management assumptions. This has implications as well for (a) the preparation of common input data for future ensemble runs aiming at the identification of differences in model algorithms globally, and (b) the interpretability of GGCM-based studies. On the other hand, the EPIC-based ensemble shows better agreement in terms of mean model bias if certain aspects of model uncertainty are eliminated (growing seasons, fertilizer application levels, and soil nutrient supply), in contrast to a non-EPIC-based ensemble which shows increasing bias.

The differences in model outputs induced by differences in setups indicate that further steps of harmonization among GGCMs should be taken if model algorithms are to be compared globally. However, prioritizing and selecting input data for further harmonization of the whole ensemble is not a straightforward process. None of the MFWs evaluated herein exhibited an outstanding performance in reproducing reported yields that would allow for justifying the selection of its maize cultivar or wheat type distribution. In order to overcome issues related to the wheat type distribution, following phases of the GGCMI project will collect winter and spring wheat simulations separately for regions in which both may be grown in order to allow for ex-post distributions according to wheat type masks. A harmonization of major maize cultivars appears less feasible in the short run due to differing scopes among research groups. Although the cultivar distribution of EPIC-IIASA performs overall better than that of GEPIC, it is as well not optimal in all regions. Producing global cultivar distribution maps may hence require the compilation of a global inventory of representative maize cultivars and their geographic distribution. Soil data will need to be harmonized to avoid differences in nutrient supply in low-input regions from SOM mineralization and especially differences in soil hydrology in regions with low precipitation under rainfed growth conditions. While a compilation of global crop management practices cannot be expected in the short run, management practices regarding the timing of fertilizer application and thresholds for automatic fertilizer and water irrigation need to be harmonized to avoid deviations among GGCMs impairing the interpretability of plant water stress. To address this issue, model runs in GGCMI phase 2 will be performed 
Biogeosciences Discuss., doi:10.5194/bg-2016-527, 2016

Manuscript under review for journal Biogeosciences

Published: 20 December 2016

(c) Author(s) 2016. CC-BY 3.0 License.

with prescribed timing and rates of fertilizer application. Plant residue management can differ substantially from farm to farm as it is subject to farm type and socio-economic drivers and may hence rather be addressed by scenario analyses in future GGCM studies.

Further harmonization of GGCMs in terms of subroutines and parameterization, on the other hand, can be expected to become a long-term process and care must be taken to ensure that the harmonized variables are a genuinely improved representation of reality, and not just a more limited sampling of the uncertainty space. Single parameters and subroutines such as PET estimation methods or microbial turnover processes are often representative for specific climatic and agro-ecologic regions. However, up to now they cannot be attributed spatially based on any available covariates in global datasets. Hence, running a range of MFWs based on the same field-scale model in different parameterizations allows meanwhile to bracket likely yield estimates by covering gaps in the understanding of agro-environmental processes. Further regional and field assessments, in combination with climate and pedologic zoning, will be required to derive reasonable spatially explicit datasets on the optimal PET estimation method, parameterization of microbial activity, and common SOM turn-over rates among others.

\section{Data availability}

Model output data will be made available via the GGCMI data archive.

\section{Acknowledgements}

We acknowledge the support and data provision by the Agricultural Intercomparison and Improvement Project (AgMIP). AA and TAMP were funded by the European Commission's 7th Framework Programme, under Grant Agreement number 603542 (LUC4C). CF, JB, NK, and RS were supported by the European Research Council Synergy Grant number ERC-2013-SynG-610028 (IMBALANCE-P).

\section{References}

Asseng, S., Ewert, F., Rosenzweig, C., Jones, J. W., Hatfield, J. L., Ruane, A. C., Boote, K. J., Thorburn, P. J., Rotter, R. P., Cammarano, D., Brisson, N., Basso, B., Martre, P., Aggarwal, P. K., Angulo, C., Bertuzzi, P., Biernath, C., Challinor, A. J., Doltra, J., Gayler, S., Goldberg, R., Grant, R., Heng, L., Hooker, J., Hunt, L. A., Ingwersen, J., Izaurralde, R. C., Kersebaum, K. C., Muller, C., Naresh Kumar, S., Nendel, C., O/'Leary, G., Olesen, J. E., Osborne, T. M., Palosuo, T., Priesack, E., Ripoche, D., Semenov, M. A., Shcherbak, I., Steduto, P., Stockle, C., Stratonovitch, P., Streck, T., Supit, I., Tao, F., Travasso, M., Waha, K., Wallach, D., White, J. W., Williams, J. R., and Wolf, J.: Uncertainty in simulating wheat yields under climate change, Nat. Clim. Change, 3, 827-832, 2013.

Balkovič, J., van der Velde, M., Schmid, E., Skalský, R., Khabarov, N., Obersteiner, M., Stürmer, B., and Xiong, W.: Pan-European crop modelling with EPIC: implementation, up-scaling and regional crop yield validation. Agric. Syst., 120, 61-75, 2013.

Balkovič, J., van der Velde, M., Skalský, R., Xiong, W., Folberth, C., Khabarov, N., Smirnov, A., Mueller, N. D., and Obersteiner, M.: Global wheat production potentials and management flexibility under the representative concentration pathways, Glob. Planet. Change, 122, 107-121, 2014. 
Biogeosciences Discuss., doi:10.5194/bg-2016-527, 2016

Manuscript under review for journal Biogeosciences

Published: 20 December 2016

(c) Author(s) 2016. CC-BY 3.0 License.

Batjes, N.H.: ISRIC-WISE derived soil properties on a 5 by 5 arc-minutes global grid. ISRIC - World Soil

Curtis, B. C.: Wheat in the world. in: Curtis, B. C., Rajaram, S., and Gómez Macpherson, H.: Bread Wheat Improvement and Production. Food and Agriculture Organization of the United Nations, Rome, 2002.

Dee, D. P., Uppala, S. M., Simmons, A. J., Berrisford, P., Poli, P., Kobayashi, S., Andrae, U., Balmaseda, M. A., Balsamo, G., Bauer, P., and Bechtold, P.: The ERA-Interim reanalysis: configuration and performance of the data assimilation system:. Q. J. R. Meteorol. Soc., 137, 553-597, 2011.

Deryng, D., Sacks, W. J., Barford, C. C., and Ramankutty, N.: Simulating the effects of climate and land management practices on global crop yield, Global Biogeochem. Cycles, 25, doi:10.1029/2009GB003765, 2011

Deryng, D., Elliott, J., Folberth, C., Müller, C., Pugh, T. A., Boote, K. J., Conway, D., Ruane, A. C., Gerten, D., Jones, J. W., Khabarov, N., , Olin, S., Schaphoff, S., Schmid, E., Yang, H., and Rosenzweig, C.: Regional disparities in the beneficial effects of rising $\mathrm{CO}_{2}$ emissions on crop water productivity, Nat. Clim. Change, 6, 786-790, 2016.

Elliott, J., Kelly, D., Chryssanthacopoulos, J., Glotter, M., Jhunjhnuwala, K., Best, N., Wilde, M., and Foster, I.: The Parallel System for Integrating Impact Models and Sectors (pSIMS), Environ. Modell. Softw., 62, 509-516, 2014.

Elliott, J., Müller, C., Deryng, D., Chryssanthacopoulos, J., Boote, K. J., Büchner, M., Foster, I., Glotter, M., Heinke, J., Iizumi, T., Izaurralde, R. C., Mueller, N. D., Ray, D. K., Rosenzweig, C., Ruane, A. C., and Sheffield, J.: The Global Gridded Crop Model Intercomparison: data and modeling protocols for Phase 1 (v1.0), Geosci. Model Dev., 8, 261-277, 2015.

Elshout, P. M. F., Van Zelm, R., Balkovič, J., Obersteiner, M., Schmid, E., Skalský, R., Van Der Velde, M., and Huijbregts, M. A. J.: Greenhouse-gas payback times for crop-based biofuels, Nat. Clim. Change, 5, 604-610, 2015.

Fader, M., Rost, S., Müller, C., Bondeau, A., and Gerten, D.: Virtual water content of temperate cereals and maize: present and potential future patterns, J. Hydrol. 384, 218-231, 2010.

FAO: FAO Digital Soil Map of the World, FAO, Rome, 1995.

FAO: FertiSTAT - Fertilizer Use Statistics, Food and Agricultural Organization of the UN, Rome, 2007.

FAO: FAOSTAT statistical database, Food and Agricultural Organization of the UN, Rome, 2014.

Folberth, C., Gaiser, T., Abbaspour, K. C., Schulin, R., and Yang, H.: Regionalization of a large-scale crop growth model for sub-Saharan Africa: model setup, evaluation, and estimation of maize yields, Agr. Ecosyst. Environ., 151, 21-33, 2012.

Folberth, C., Yang, H., Gaiser, T., Liu, J., Wang, X., Williams, J., and Schulin, R.: Effects of ecological and conventional agricultural intensification practices on maize yields in sub-Saharan Africa under potential climate change, Environ. Res. Lett., 9, 044004, 2014.

Folberth, C., Skalský, R., Moltchanova, E., Balkovič, J., Azevedo, L. B., Obersteiner, M., and van der Velde, M.: Uncertainty in soil data can outweigh climate impact signals in global crop yield simulations, Nat. Commun., 7, 11872, 2016. 
Biogeosciences Discuss., doi:10.5194/bg-2016-527, 2016

Manuscript under review for journal Biogeosciences

Published: 20 December 2016

(c) Author(s) 2016. CC-BY 3.0 License.

Frank, S., Schmid, E., Havlík, P., Schneider, U.A., Balkovič, J., Obersteiner, M., and Böttcher, H.: The dynamic soil carbon mitigation potential of European cropland, Global Environmental Change, 35, 269-278, 2015.

Havlík, P., Schneider, U. A., Schmid, E., Böttcher, H., Fritz, S., Skalský, R., Aoki, K., Cara, S. D., Kindermann, G., Kraxner, F., Leduc, S., McCallum, I., Mosnier, A., Sauer, T., and Obersteiner, M.: Global land-use implications of first and second generation biofuel targets, Energy Policy, 39, 5690-5702, 2011.

Gaiser, T., de Barros, I., Sereke, F., and Lange, F.-M.: Validation and reliability of the EPIC model to simulate maize production in small-holder farming systems in tropical sub-humid West Africa and semi-arid Brazil, Agr. Ecosyst. Environ., 135, 318-327, 2010.

Gassman, P. W., Williams, J. R., Benson, V. W., Izaurralde, R. C., Hauck, L. M., Jones, C. A., Atwood, J. D., Kiniry, J. R., and Flowers, J. D.: Historical Development and Applications of the EPIC and APEX models, ASAE/CSAE Meeting Paper No. 042097, 2004.

Gavilán, P., Lorite, I. J., Tornero, S., and Berengena, J.: Regional calibration of Hargreaves equation for estimating reference ET in a semiarid environment, Agr. Water Manage., 81, 257-281, 2006.

Gelfand, I., Sahajpal, R., Zhang, X., Izaurralde, R. C., Gross, K. L., and Robertson, G. P.: Sustainable bioenergy production from marginal lands in the US Midwest, Nature, 493, 514-517, 2013.

Gbegbelegbe, S., Cammarano, D., Asseng, S., Robertson, Richard D., Chung, U., Adam, M., Abdalla, O., Payne, T., Reynolds, M., Sonder, K., Shiferaw, B., and Nelson, G. C.: Baseline simulation for global wheat production with CIMMYT mega-environment specific cultivars, Field Crops Res., in press. http://dx.doi.org/10.1016/j.fcr.2016.06.010, 2016

Gerik, T., Williams, J., Francis, L., Greiner, J., Magre, M., Meinardus, A., Steglich, E., and Taylor, R.: Environmental Policy Integrated Climate Model - User's Manual Version 0810, Blackland Research and Extension Center, Texas A\&M AgriLife, Temple, USA, 2014.

Hargreaves, G. H., and Samani, Z. A.: Reference crop evapotranspiration from temperature, Applied Engr. Agric., 1, 96-99, 1985.

Hempel, S., Frieler, K., Warszawski, L., Schewe, J., and Piontek, F.: A trend-preserving bias correction - the ISI-MIP approach, Earth Syst. Dynam., 4, 219-236, 2013.

Izaurralde, R. C., Williams, J. R., McGill, W. B., Rosenberg, N. J., and Quiroga Jakas, M. C.: Simulating soil C dynamics with EPIC: model description and testing against long-term data, Ecol. Model., 192, 362384,2006

Izaurralde, R. C., McGill, W. B., and Williams, J. R.: Development and application of the EPIC model for carbon cycle, greenhouse gas mitigation, and biofuel studies, in: Liebig, M. A., Franzluebbers, A. J., and Follet, R. F.: Managing Agricultural Greenhouse Gases, Academic Press, San Diego, USA, 2012.

Kiniry, J. R., Major, D.J., Izaurralde, R.C., Williams, J.R., Gassman, P.W., Morrison, M., Bergentine, R., and Zentner, R.P.: EPIC model parameters for cereal, oilseed, and forage crops in the northern Great Plains region, Can. J. Plant Sci., 75, 679-688, 1995.

Kuhn, A., Gaiser, T., and Gandonou, E.: Simulating the effects of tax exemptions on fertiliser use in Benin by linking biophysical and economic models, Agric. Syst., 103, 509-520, 2010.

Liu, J., Williams, J. R., Zehnder, A. J. B., and Yang, H.: GEPIC - modelling wheat yield and crop water productivity with high resolution on a global scale, Agric. Syst., 94, 478-493, 2007. 
Biogeosciences Discuss., doi:10.5194/bg-2016-527, 2016

Manuscript under review for journal Biogeosciences

Published: 20 December 2016

(c) Author(s) 2016. CC-BY 3.0 License.

Liu, J.: A GIS-based tool for modelling large-scale crop-water relations, Environ. Modell. Softw., 24, 411-422, 2009.

Liu, J., Folberth, C., Yang, H., Rockström, J., Abbaspour, K., and Zehnder, A. J. B.: A global and spatially explicit assessment of climate change impacts on crop production and consumptive water use, PLoS ONE, 8, e57750, 2013.

Liu, W., Yang, H., Folberth, C., Wang, X., Luo, Q., and Schulin, R.: Global investigation of impacts of PET methods on simulating crop-water relations for maize, Agr. Forest. Meteorol., 221, 164-175, 2016a.

Liu, W., Yang, H., Liu, J., Azevedo, L. B., Wang, X., Xu, Z., Abbaspour, K. C., and Schulin, R.: Global assessment of nitrogen losses and trade-offs with yields from major crop cultivations, Sci. Total Environ., 572, 526-537, 2016b.

Lychuk, T. E., Izaurralde, R. C., Hill, R. L., McGill, W. B., and Williams, J. R.: Biochar as a global change adaptation: predicting biochar impacts on crop productivity and soil quality with the EPIC model, Mitig. Adapt. Strateg. Glob. Change, 20, 1437-1458, 2015.

McGill, W. B., Hunt, H. W., Woodmansee, R. G., and Reuss, J. O.: Phoenix, a model of the dynamics of carbon and nitrogen in grassland soils, in: Clark, F. E. and Rosswall, T.: Terrestrial Nitrogen Cycles. Processes, Ecosystem Strategies and Management Impacts, Ecological Bullettins, 49-115, Stockholm, 1981.

Mueller, N. D., Gerber, J. S., Johnston, M., Ray, D. K., Ramankutty, N., and Foley, J. A.: Closing yield gaps through nutrient and water management, Nature, 490, 254-257, 2012.

Müller, C.: Agriculture: harvesting from uncertainties, Nature Clim. Change, 1, 253-254, 2011.

Müller, C., Elliott, J., Chryssanthacopoulos, J., Deryng, D., Folberth, C., Pugh, T. A., and Schmid, E.: Implications of climate mitigation for future agricultural production, Environ. Res. Lett., 10, 125004, 2015.

Müller, C., Elliott, J., Chryssanthacopoulos, J., Arneth, A., Balkovič, J., Ciais, P., Deryng, D., Folberth, C., Glotter, M., Hoek, S., Iizumi, T., Izaurralde, R. C., Jones, C., Khabarov, N., Lawrence, P., Liu, W., Olin, S., Pugh, T. A. M., Ray, D., Reddy, A., Rosenzweig, C., Ruane, A. C., Sakurai, G., Schmid, E., Skalský, R., Song, C. X., Wang, X., de Wit, A., and Yang, H.: Global Gridded Crop Model evaluation: benchmarking, skills, deficiencies and implications, Geoscientific Model Development Discussions, doi: 10.5194/gmd-2016-207, 2016.

Nelson, G. C., Valin, H., Sands, R. D., Havlík, P., Ahammad, H., Deryng, D., Elliott, J., Fujimori, S., Hasegawa, T., Heyhoe, E., Kyle, P., Von Lampe, M., Lotze-Campen, H., Mason d'Croz, D., van Meijl, H., van der Mensbrugghe, D., Müller, C., Popp, A., Robertson, R., Robinson, S., Schmid, E., Schmitz, C., Tabeau, A., and Willenbockel, D.: Climate change effects on agriculture: Economic responses to biophysical shocks, Proc. Natl. Acad. Sci., 111, 3274-3279, 2014.

Nuttonson, M.Y.: Wheat-climatic relationships and the use of phenology in ascertaining the thermal and photothermal requirements of wheat, American Institute of Crop Ecology, Washington, D. C., 1955.

Porwollik, V., Müller, C., Elliott, J., Chryssanthacopoulos, J., Iizumi, T., Ray, D. K., Ruane, A. C., Arneth, A., Balkovič, J., Ciais, P., Deryng, D., Folberth, C., Izaurralde, R. C., Jones, C. D., Khabarov, N., 
Biogeosciences Discuss., doi:10.5194/bg-2016-527, 2016

Manuscript under review for journal Biogeosciences

Published: 20 December 2016

(c) Author(s) 2016. CC-BY 3.0 License.

Wu, X.: Spatial and temporal uncertainty of crop yield aggregations, Eur. J. Agron., doi: 10.1016/j.eja.2016.08.006, 2016.

Portmann, F. T., Siebert, S., and Döll, P.: MIRCA2000 - Global monthly irrigated and rainfed crop areas around the year 2000: A new high-resolution dataset for agricultural and hydrological modeling, Global Biogeochem. Cy., 24, GB 1011, doi:10.1029/2008GB003435, 2010.

$\mathrm{R}$ Development Core Team: R: A language and environment for statistical computing, $\mathrm{R}$ Foundation for Statistical Computing, Vienna, Austria, https://www.R-project.org, 2008.

Ray, D. K., Ramankutty, N., Mueller, N. D., West, P. C., and Foley, J. A.: Recent patterns of crop yield growth and stagnation, Nat. Comm., 3, 1293, 2012.

Rosenzweig, C., Jones, J. W., Hatfield, J. L., Ruane, A. C., Boote, K. J., Thorburn, P., Antle, J. M., Nelson, G. C., Porter, C., Janssen, S., Asseng, S., Basso, B., Ewert, F., Wallach, D., Baigorria, G., and Winter, J. M.: The Agricultural Model Intercomparison and Improvement Project (AgMIP): Protocols and pilot studies, Agr. Forest Meteorol., 170, 166-182, 2013.

Rosenzweig, C., Elliott, J., Deryng, D., Ruane, A. C., Arneth, A., Boote, K. J., Folberth, C., Glotter, M., Khabarov, N., Müller, C., Neumann, K., Piontek, F., Pugh, T., Schmid, E., Stehfest, E., and Jones, J. W.: Assessing agricultural risks of climate change in the 21 st century in a global gridded crop model intercomparison, Proc. Natl. Acad. Sci., 111, 3268-3273, 2014.

Sacks, W.J., Deryng, D., Foley, J.A., and Ramankutty, N.: Crop planting dates: An analysis of global patterns, Global Ecol. Biogeogr., 19, 607-620, 2010.

Schaap, M. G. and Bouten, W.: Modelling water retention curves of sandy soils using neural networks, Water Resour. Res., 32, 3033-3040, 1996.

Schneider, U. A., Havlík, P., Schmid, E., Valin, H., Mosnier, A., Obersteiner, M., Böttcher, H., Skalský, R., Balkovič, J., Sauer, T., and Fritz, S.: Impacts of population growth, economic development, and technical change on global food production and consumption, Agric. Syst., 104, 204-215, 2011.

Schneider, U., Becker, A., Finger, P., Meyer-Christoffer, A., Zuise, M., and Rudolf, B.: GPCC's new land surface precipitation climatology based on quality - controlled in situ data and its role in quantifying the global water cycle, Theor. Appl. Climatol., 115, 15-40, 2013.

Skalský, R., Tarasovičová, Z., Balkovič, J., Schmid, E., Fuchs, M., Moltchanova, E., Kindermann, G., and Scholtz, P.: Geo-bene global database for biophysical modelling v. 1.0. Concepts, methodologies and data, 2008.

Stehfest, E., Heistermann, M., Priess, J. A., Ojima, D. S., and Alcamo, J.: Simulation of global crop production with the ecosystem model DayCent, Ecol. Model., 209, 203-219, 2007.

Stoeckle, C. O., Williams, J. R., Jones, C. A., and Rosenberg, N. J.: A method for estimating the direct and climatic effects of rising atmospheric carbon dioxide on growth and yield of crops. I. Modification of the EPIC model for climate change analysis, Agric. Syst., 38, 225-238, 1992.

Stolbovoy, V., Montanarella, L., and Panagos, P. (eds.): Carbon Sink Enhancement in Soils of Europe: Data, Modeling, Verification, JRC technical and scientific reports, Office for Official Publications of the European Communities, Luxembourg, 2007.

Waha, K., van Bussel, L. G. J., Müller, C., and Bondeau, A.: Climate-driven simulation of global crop sowing dates, Global Ecol. Biogeogr., 21, 247-259, 2012. 
Biogeosciences Discuss., doi:10.5194/bg-2016-527, 2016

Manuscript under review for journal Biogeosciences

Published: 20 December 2016

(c) Author(s) 2016. CC-BY 3.0 License.

Warnes, G. R., Bolker, B., Bonebakker, L., Gentleman, R., Huber, W., Liaw, A., Lumley, T., Maechler, M., Magnusson, A., Moeller, S., Schwartz, M., and Venables, B.: gplots: Various R Programming Tools for Plotting Data. R package version 3.0.1, 2016.

Warszawski, L., Frieler, K., Huber, V., Piontek, F., Serdeczny, O., and Schewe, J.: The Inter-Sectoral Impact Model Intercomparison Project (ISI-MIP): Project framework, Proc. Natl. Acad. Sci., 111, 3228-3232, 2013.

Weedon, G. P., Balsamo, G., Bellouin, N., Gomes, S., Best, M. J., and Viterbo, P.: The WFDEI meteorological forcing data set: WATCH Forcing Data methodology applied to ERA-Interim reanalysis data, Water Resour. Res., 50, 7505-7514, 2014.

890 Wickham, H.: ggplot2: Elegant Graphics for Data Analysis, Springer, New York, 2009.

Williams, J. R., Jones, C. A., Kiniry, J. R., and Spanel, D. A.: The EPIC crop growth model, Trans. ASAE, 32, 497-511, 1989.

Wösten, J. H. M. and Van Genuchten, M. T.: Using texture and other soil properties to predict the unsaturated soil hydraulic functions, Soil. Sci. Soc. Am. J., 52, 1762-1770, 1988.

Xiong, W., Balkovič, J., van der Velde, M., Zhang, X., Izaurralde, R. C., Skalský, R., Lin, E., Mueller, N., and Obersteiner, M.: A calibration procedure to improve global rice yield simulations with EPIC, Ecological Modelling, 273, 128-139, 2014a.

Xiong, W., van der Velde, M., Holman, I. P., Balkovič, J., Lin, E., Skalský, R., Porter, C., Jones, J., Khabarov, N., and Obersteiner, M.: Can climate-smart agriculture reverse the recent slowing of rice yield growth in China?, Agriculture, Ecosystems \& Environment, 196, 125-136, 2014b.

Xiong, W., Skalský, R., Porter, C. H., Balkovič, J., Jones, J. W., and Yang, D.: Calibration-induced uncertainty of the EPIC model to estimate climate change impact on global maize yield, J. Adv. Model. Earth Syst., 8, 1358-1375, 2016.

Zhang, X., Izaurralde, R. C., Manowitz, D. H., Sahajpal, R., West, T. O., Thomson, A. M., Xu, M., Zhao, K., 905 LeDuc, S. D., and Williams, J. R.: Regional scale cropland carbon budgets: evaluating a geospatial agricultural modeling system using inventory data, Environ. Modell. Softw., 63, 199-216, 2015. 
Biogeosciences Discuss., doi:10.5194/bg-2016-527, 2016

Manuscript under review for journal Biogeosciences

Published: 20 December 2016

Table 1: Selected parameters and choices of subroutines for the participating EPIC model frameworks (MFWs). A dash indicates that the variable is not relevant for the respective MFW, e.g. the soil erosion estimation method if soil erosion is not taken into account in the MFW.

\begin{tabular}{|c|c|c|c|c|c|}
\hline Parameter & EPIC-BOKU & EPIC-IIASA & EPIC-TAMU & GEPIC & PEPIC \\
\hline ET estimation method & PM & HG & PM & HG & PM \\
\hline Wind erosion considered ${ }^{11)}$ & no & no & yes & yes & yes \\
\hline Water erosion considered $^{1)}$ & annual & no & no & yes & yes \\
\hline Field length for wind erosion & - & 2.00 & 1.00 & 1.24 & 2.00 \\
\hline Field width for wind erosion & - & 2.00 & 1.00 & 0.62 & 2.00 \\
\hline Soil variable dependence of $\mathrm{CN}^{2}$ ) & SMI & depth & depth & SMI & SMI \\
\hline FC and WP estimation 3 ) & Rawls & static input & Rawls & Rawls & Rawls \\
\hline Denitrification method & EPIC & $\mathrm{Cl}$ & $\mathrm{Cl}$ & $\mathrm{Cl}$ & $\mathrm{AK}$ \\
\hline Automatic fertilizer application trigger ${ }^{4)}$ & 0.9 & 0.8 & 0.99 & 0.9 & 0.0 \\
\hline Water erosion conservation practice ${ }^{5)}$ & 1.0 & 0.0 & 0.0 & 0.5 & 1.0 \\
\hline Layer thickness for gas diffusion & 0.1 & 0.0 & 0.2 & 0.1 & 0.0 \\
\hline Water erosion estimation method & RUSLE & - & - & MUSS & RUSL2 \\
\hline Denitrification rate constant & 0.01 & 1 & 0.5 & 0.01 & 0.05 \\
\hline Soil evaporation coefficient & 2.5 & 1.5 & 2.5 & 2.5 & 1.5 \\
\hline Hargreaves exp. coefficient & - & 0.6 & - & 0.5 & - \\
\hline Hargreaves linear coefficient & - & 0.0023 & - & 0.0032 & - \\
\hline Layer depth for soluble $\mathrm{P}$ tracking & 0.3 & 0.3 & 0.05 & 0.1 & 0.1 \\
\hline Microbial decay rate & 1 & 0.1 & 1 & 1 & 1 \\
\hline Denitrification soil water threshold & 0.99 & 1 & 0.65 & 0.99 & 1.01 \\
\hline Soil evaporation-cover coefficient & 0 & 0 & 0.15 & 0 & 0 \\
\hline CN number index coefficient & 1.5 & 1.2 & 1 & 0.5 & 1 \\
\hline Slow to passive humus coefficient & 0.05 & 0.05 & 0.003 & 0.05 & 0.05 \\
\hline Oxygen coefficient for microbial activity & 0.9 & 0.99 & 0.8 & 0.9 & 0.9 \\
\hline Coefficient allocating root growth & 0.5 & 0.5 & 0.7 & 0.5 & 0.5 \\
\hline $\mathrm{N}$ volatilization coefficient & 0.005 & 0.7 & 0.03 & 0.005 & 0.3 \\
\hline
\end{tabular}

1) Annual renewal of soil profile if a static soil profile is used and wind/water erosion is turned on

2) Describes the dependence of curve number (CN) estimation on soil moisture, which can be based on five methods, among them soil moisture gradient with profile depth or calculation of a daily soil moisture index (SMI)

${ }^{3)}$ Field capacity (FC) and wilting point (WP) can be estimated by 10 different methods - among them Rawl's method used by most MFWs or be input directly after prior estimation, which is the case for EPIC-IIASA where the Rosetta model had been applied a priori.

4) The auto-fertilizer and irrigation triggers define at which stress level fertilizer or water are being applied. E.g., a value of 0.8 for the autofertilizer trigger implies that fertilizer is applied on a given day if potential biomass production would be limited by $>20 \%$. Zero indicates that fertilizer or irrigation water is not applied automatically. 
Biogeosciences Discuss., doi:10.5194/bg-2016-527, 2016

Manuscript under review for journal Biogeosciences

Published: 20 December 2016

Table 2: Crop management scenarios based on Elliott et al. (2015). The default setup represents each modelling group's own assumptions and input data. The harmonized scenarios use the same growing season data and the same annual application rates for $\mathbf{N}$ and $\mathbf{P}$ (fullharm) or sufficient nutrient supply (harm-suffN) to avoid plant growth limitations.

\begin{tabular}{|c|c|c|c|c|c|}
\hline Name & Abbreviation & $\begin{array}{l}\text { Irrigation vol. } \\
\qquad[\mathrm{mm}]\end{array}$ & $\begin{array}{c}\mathrm{N} \\
{\left[\mathrm{kg} \mathrm{ha}^{-1}\right]}\end{array}$ & $\begin{array}{c}\mathrm{P} \\
{\left[\mathrm{kg} \mathrm{ha}^{-1}\right]}\end{array}$ & Season \\
\hline Default irrigated & def-ir & sufficient & ${\text { individual }{ }^{11}}$ & individual $^{1)}$ & individual $^{11}$ \\
\hline Default rainfed & def-rf & - & ${\text { individual }{ }^{1)}}$ & individual $^{1)}$ & ${\text { individual }{ }^{1)}}$ \\
\hline Fully harmonized irrigated & harm-ir & sufficient & harmon.2) & harmon.2) & harmon.3) \\
\hline Fully harmonized rainfed & harm-rf & - & harmon. ${ }^{2)}$ & harmon. ${ }^{2)}$ & harmon. ${ }^{3)}$ \\
\hline Harmonized \& suff. nutrients irrig. & harm-suffN-ir & sufficient & sufficient & sufficient & harmon. ${ }^{3 l}$ \\
\hline Harmonized \& suff. nutrients rainfed & harm-suffN-rf & - & sufficient & sufficient & harmon. ${ }^{3)}$ \\
\hline
\end{tabular}

${ }^{1)}$ Based on each research group's assumptions and data

2) Harmonized fertilizer application rates based on Mueller et al. (2010) processed as described in Elliott et al. (2015)

${ }^{3)}$ Harmonized growing season data based on Sacks et al. (2010) with gap filling as described in Elliott et al. (2015)

Table 3: Evaluation matrix for detailed comparison of GEPIC and EPIC-IIASA using the rainfed fully harmonized (fullharm) scenario.

\begin{tabular}{|c|c|c|c|}
\hline $\begin{array}{l}\text { Setup } \\
\text { component }\end{array}$ & EPIC-IIASA & GEPIC & Major effects \\
\hline $\begin{array}{l}\text { Cultivars } \\
\text { (Cult) }\end{array}$ & - see Figure 1 and Table S1-1 & - see Figure 1 and Table S1-1 & $\begin{array}{l}\text { - scaling of yields } \\
\text { - higher sensitivity to water stress } \\
\text { with low-yielding cultivar } 4\end{array}$ \\
\hline $\begin{array}{l}\text { Soil data } \\
\text { (SoilD) }\end{array}$ & $\begin{array}{l}\text { - generalized profiles from } \\
\text { ISRIC-WISE soil database }\end{array}$ & $\begin{array}{l}\text { - ISRIC-WISE mapped to } \\
\text { Digital Soil Map of the } \\
\text { World }\end{array}$ & $\begin{array}{l}\text { - differences in soil properties, } \\
\text { e.g. soil hydrology and soil } \\
\text { composition }\end{array}$ \\
\hline $\begin{array}{l}\text { Soil handling } \\
\text { (SoilP) }\end{array}$ & - transient runs & $\begin{array}{l}\text { - decadal runs with soil } \\
\text { renewal (see Figure S1-1) }\end{array}$ & $\begin{array}{l}\text { - carry-over effects in transient } \\
\text { runs }\end{array}$ \\
\hline $\begin{array}{l}\text { Crop } \\
\text { management } \\
\text { (Manage) }\end{array}$ & $\begin{array}{l}\text { - one ploughing operation } \\
\text { - plant residue left on field }\end{array}$ & $\begin{array}{l}\text { - two cultivation operations } \\
\text { - residue removal after harvest }\end{array}$ & $\begin{array}{l}\text { - } \text { nutrient availability } \\
\text { - soil dynamics (erosion, nutrient } \\
\text { content, OC) }\end{array}$ \\
\hline $\begin{array}{l}\text { Miscellaneous } \\
\text { coefficients } \\
\text { (Coeff) }\end{array}$ & $\begin{array}{l}\text { - static soil profile } \\
\text { - adjusted Hargreaves } \\
\text { exponential coefficient } \\
\text { - fertilizer application trigger } \\
20 \% \mathrm{~N} \text { deficit }\end{array}$ & $\begin{array}{l}\text { - dynamic soil profile } \\
\text { - adjusted Hargreaves linear } \\
\text { coefficient } \\
\text { - fertilizer application trigger } \\
10 \% \mathrm{~N} \text { deficit }\end{array}$ & $\begin{array}{l}\text { - inter-annual soil nutrient } \\
\text { dynamics } \\
\text { - ET estimates and water stress } \\
\text { - timing of fertilizer application } \\
\text { - estimation of run-off and soil } \\
\text { processes }\end{array}$ \\
\hline
\end{tabular}


Biogeosciences Discuss., doi:10.5194/bg-2016-527, 2016

Manuscript under review for journal Biogeosciences

Published: 20 December 2016

(c) Author(s) 2016. CC-BY 3.0 License.

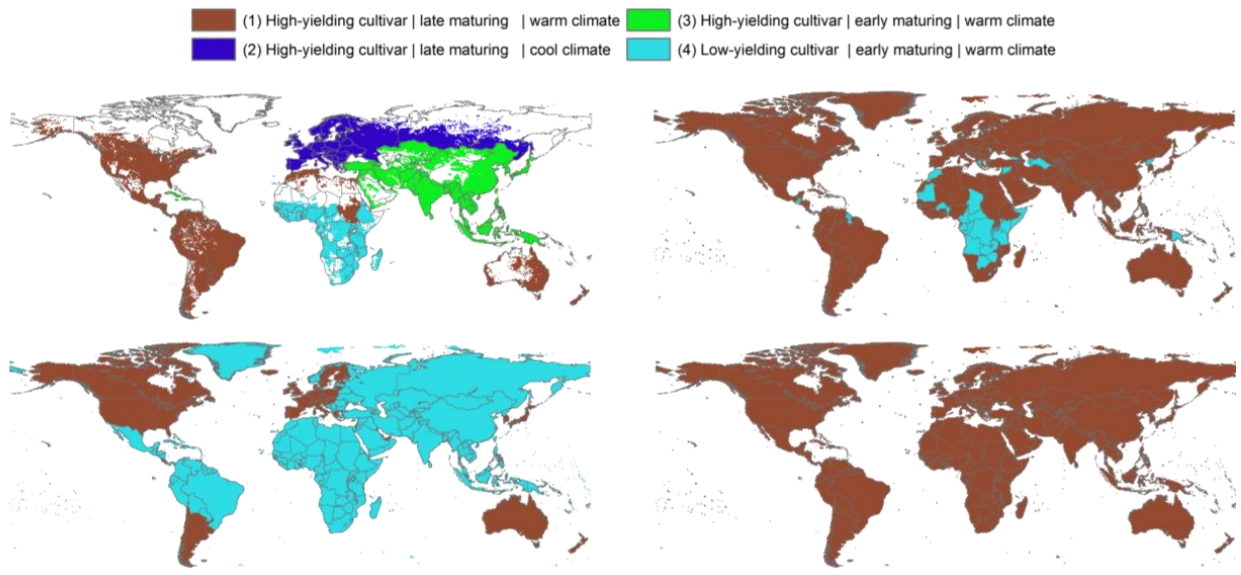

Figure 1: Distributions of maize cultivars in the model frameworks for (a) EPIC-IIASA, (b) EPIC-TAMU, (c) GEPIC and PEPIC, and (d) EPIC-BOKU. Differences in the parameterization of each cultivar are provided in Table S1-1. Numbers in braces (1-4) are used in the text to refer to the cultivars.
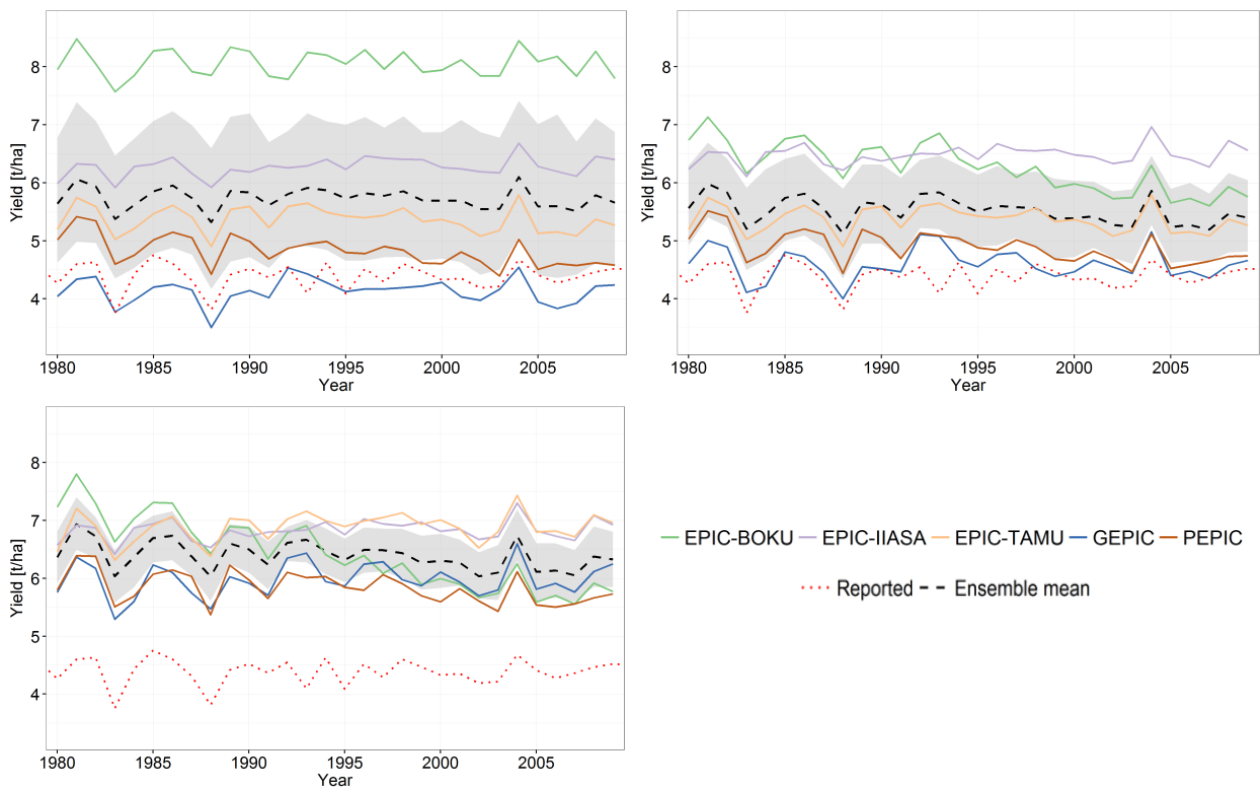

$$
\text { -... Reported - - Ensemble mean }
$$

965 Figure 2: Global average area-weighted maize yield estimates of five EPIC-MFWs for the (a) default, (b) fully harmonized (fullharm), and (c) fully harmonized scenario with sufficient nutrient supply (harm-suffN) management scenario (Table 2). Reported yields are based on FAOSTAT (FAO, 2014) and have been detrended with a seven-year moving average (Elliott et al. 2015). The black dashed line represents the ensemble mean. The grey ribbon shows the 95\% confidence interval of the mean. For EPIC-TAMU, outputs from the fully harmonized (fullharm) simulations were used as a substitute for missing default outputs to keep the number of EPIC-MFWs across management scenarios constant. 
Biogeosciences Discuss., doi:10.5194/bg-2016-527, 2016

Manuscript under review for journal Biogeosciences

Published: 20 December 2016

(C) Author(s) 2016. CC-BY 3.0 License.

(c) (i)

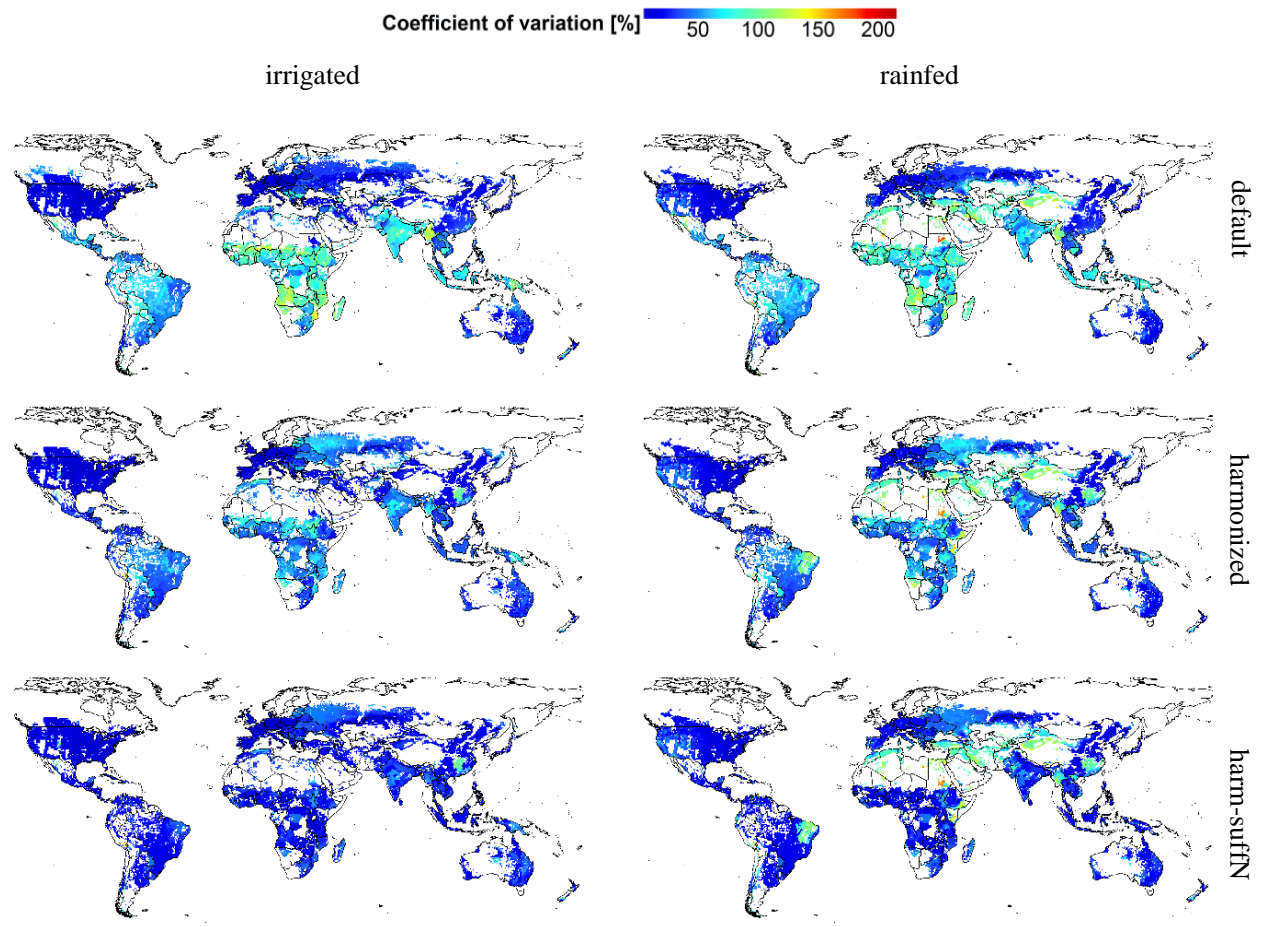

Figure 3: Coefficient of variation for maize yield estimates among EPIC-MFWs for each of the six crop management scenarios defined in Table 2. For EPIC-TAMU, outputs from the fully harmonized (fullharm) simulations were used as a substitute for missing default outputs to keep the number of EPIC-MFWs across management scenarios constant.

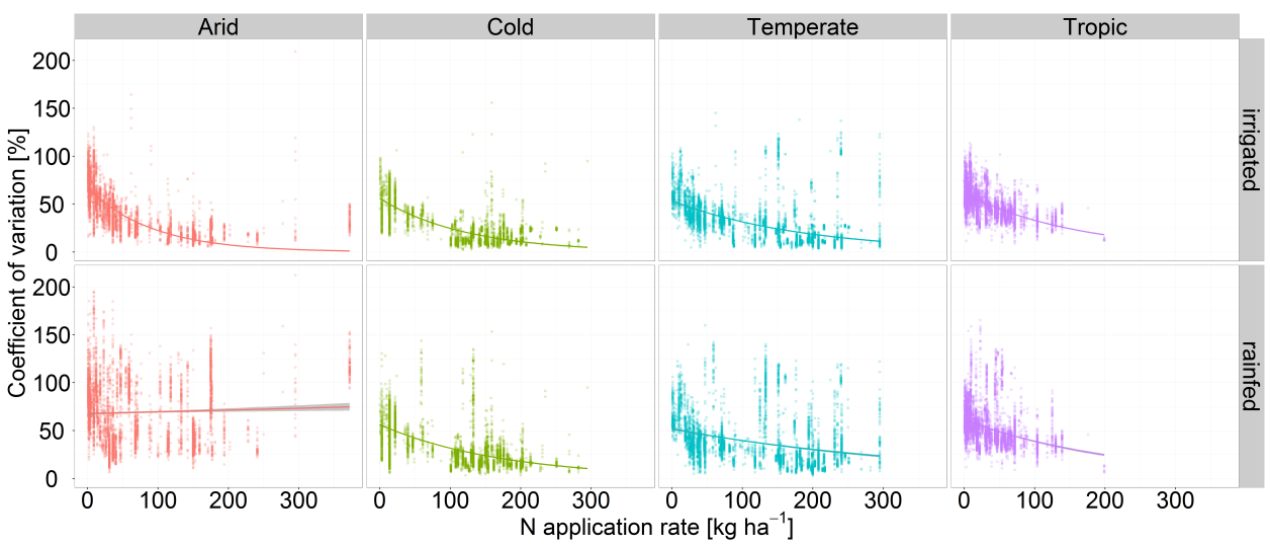

Figure 4: Coefficient of variation for maize yields among EPIC-MFWs compared to fertilizer application rates in the fully harmonized (fullharm) management scenario with sufficiently irrigated (upper row) or rainfed (lower row) water supply in each grid cell of four major climate regions. 
Biogeosciences Discuss., doi:10.5194/bg-2016-527, 2016

Manuscript under review for journal Biogeosciences

Published: 20 December 2016

(c) Author(s) 2016. CC-BY 3.0 License.

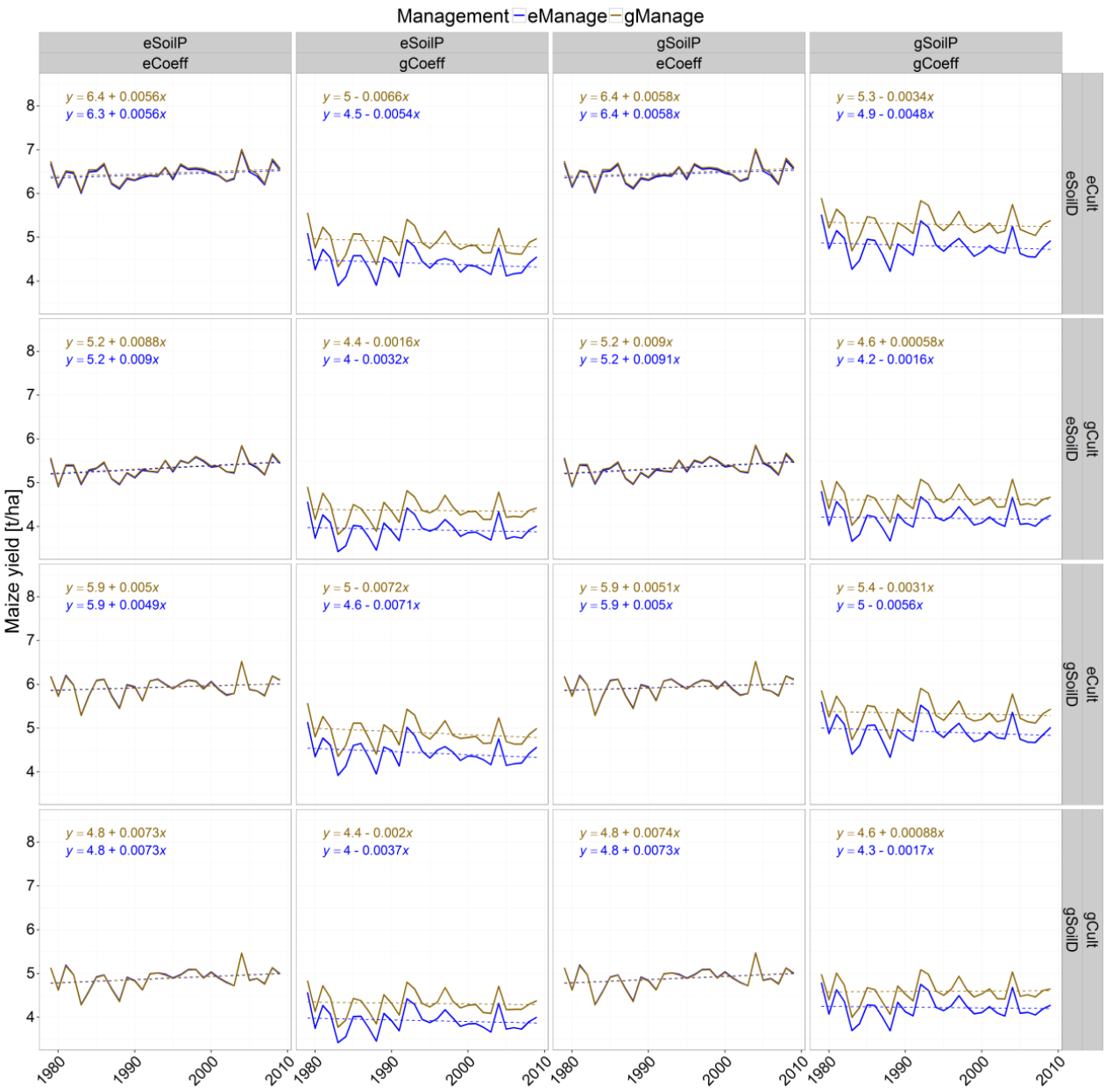

990

Figure 5: Global average rainfed maize yields over a 31 year time period for 32 setup combinations based on the EPIC-IIASA and GEPIC setups as described in Table 3. e=EPIC-IIASA, $g=$ GEPIC, Cult=cultivar definition and distribution, SoilD=soil data, SoilP=spin-up and soil handling, Coeff=coefficients, Manage=crop management (indicated by line color). Dashed lines show linear regressions to identify trends. 
Biogeosciences Discuss., doi:10.5194/bg-2016-527, 2016

Manuscript under review for journal Biogeosciences

Published: 20 December 2016

(c) Author(s) 2016. CC-BY 3.0 License.

(c) (1)

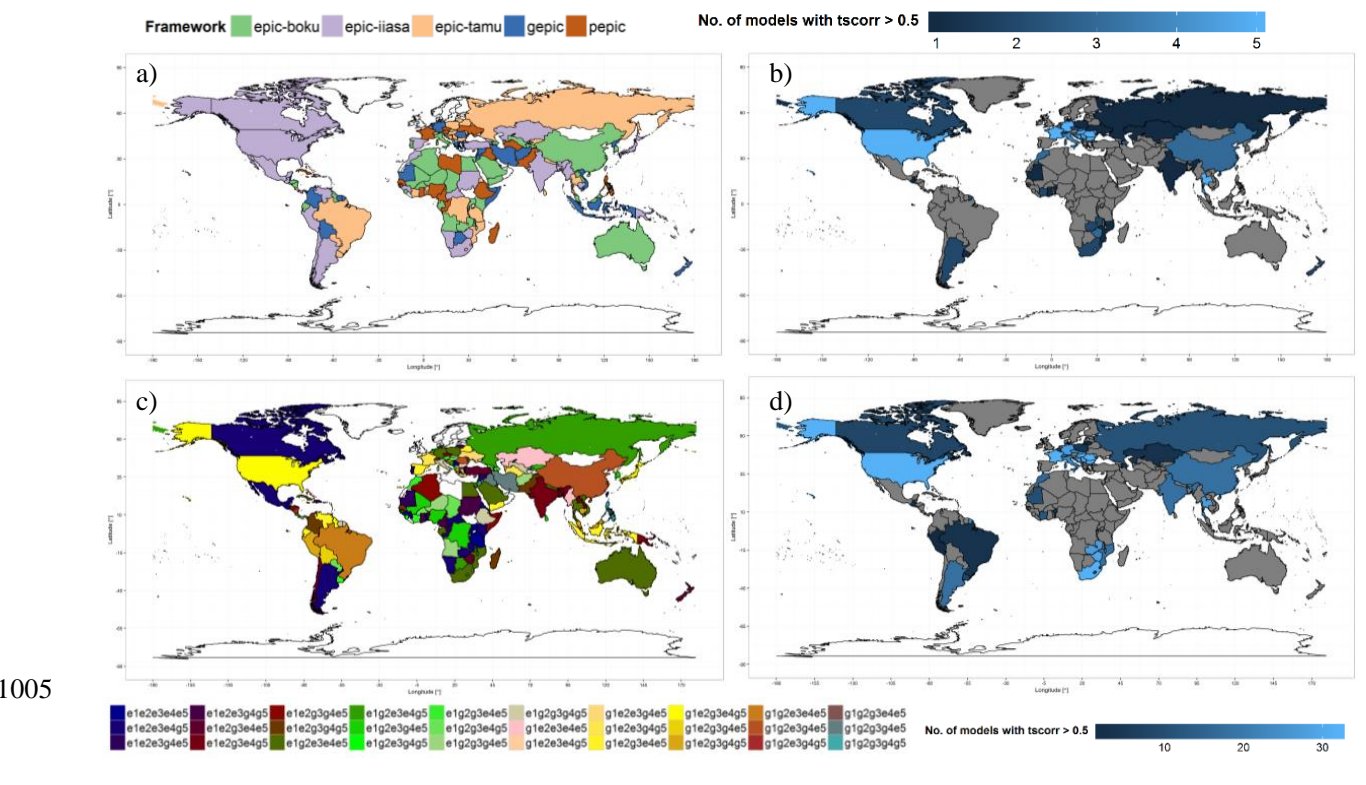

Figure 6: EPIC-MFWs and setup scenarios showing the best performance in each country regarding time-series correlation (tscorr) factor r. (a) EPIC-MFWs with best performance for maize and (b) number of EPIC-MFWs in each country with $\mathbf{r}>\mathbf{0 . 5}$. (c) EPIC setup permutation showing the best performance for maize and (d) number of EPIC setup permutations with $r>0.5$. Model outputs were post-processed by moving average detrending and meanscale correction. Number codes in the legend of panel (c) refer to $1=$ cultivar, $2=$ soil data, $3=$ =soil handling, $4=$ coefficient, and $5=$ management, letters to $\mathrm{e}=\mathrm{EPIC}$-IIAS and $\mathrm{g}=$ GEPIC. 